\title{
Regional Inflation, Banking Integration, and Dollarization*
}

\author{
Martin Brown ${ }^{1}$, Ralph De Haas ${ }^{2}$, and Vladimir Sokolov ${ }^{3}$ \\ ${ }^{1}$ University of St. Gallen, ${ }^{2}$ European Bank for Reconstruction and Development and Tilburg \\ University, and ${ }^{3} \mathrm{ICEF}$, National Research University Higher School of Economics
}

\begin{abstract}
We exploit variation in consumer price inflation across seventy-one Russian regions to examine the relationship between the perceived stability of the domestic currency and financial dollarization. Our results show that regions with higher inflation experience an increase in the dollarization of household deposits and a decrease in the dollarization of loans. The impact of inflation on credit dollarization is weaker in regions with less integrated banking markets. This suggests that the currencyportfolio choices of households and firms are constrained by the asset-liability management of banks.
\end{abstract}

JEL classification: E31, E44, F36, G21, P22, P24

Keywords: Financial dollarization, Banking integration, Regional inflation

Received April 4, 2017; accepted April 4, 2017 by Editor Franklin Allen.

\section{Introduction}

Financial dollarization-the widespread holding of assets and liabilities in a foreign currency-is viewed as both a constraint on monetary policy (Ongena, Schindele, and Vonnák, 2015) and a threat to financial stability in many emerging markets. In the aftermath of the global financial crisis, policy makers have emphasized the need to de-dollarize (or deeuroize) deposits and loans, particularly in Latin America and Eastern Europe (Garcia-

* The authors would like to thank Toman Barsbai, Cagatay Bircan, Salvatore Capasso, Sergei Guriev, Lukas Menkhoff, Alexander Plekhanov, Natalia Podlich, Alberto Pozzolo, Koen Schoors, Maria Semenova, Assaf Razin, Laura Solanko, Neven Valev, Jeromin Zettelmeyer, participants at the 2014 European Economic Association Meetings, the 2014 Royal Economic Society Meetings, the 2014 International Economic Association Meetings, the 4th MoFiR Workshop on Banking (Kobe), the 32nd International Symposium on Money, Banking and Finance (Nice) and seminar participants at Cass Business School, DIW (Berlin), EBRD, the Higher School of Economics, iCare 2014 (Perm) and the EMG-ECB Emerging Markets Finance Conference 2014 (London) for useful comments. The views are those of the authors and do not necessarily reflect those of the EBRD. 
Escribano and Sosa, 2011). A credible monetary policy that results in low and stable consumer price inflation is often seen as a key ingredient to kick-start de-dollarization. The first objective of this paper is therefore to examine to what extent the stability of the domestic currency affects the propensity of households and firms to hold foreign currency assets (deposits) and liabilities (loans).

Our second objective is to assess how the level of banking integration affects the relationship between inflation and financial dollarization. We illustrate in a concise theoretical model that regional banking integration matters because non-integrated banks need to locally intermediate an inflation-driven excess supply of foreign currency deposits whereas integrated banks can distribute such deposits to other regions. That is, integrated banking markets allow households and firms to respond to local inflation shocks by adjusting both their assets and liabilities. In contrast, in less-integrated banking markets the asset-liability management of banks constrains the currency-portfolio choices of households and firms.

We exploit variation in consumer price inflation across Russian regions to examine the relationship between the perceived stability of the domestic currency and financial dollarization. Our analysis is based on quarterly data on consumer price inflation for seventy-one regions over the period 2005:Q2 to 2014:Q2. We match these regional inflation data with information on the currency composition of bank deposits and loans, again at the regional level.

We show that regions with higher inflation experience higher dollarization of household deposits. Regions with higher inflation also feature a lower dollarization of loans to firms in non-tradable sectors and to households. In contrast, the currency composition of loans to firms in tradable sectors is unaffected by regional inflation. Together these results suggest that locally observed consumer price inflation serves as a private signal for the stability of the local currency vis-à-vis foreign currencies and thus affects the preferred currency composition of households' and firms' portfolios. Our results are robust to various model specifications and also hold in an instrumental variables (IVs) framework that exploits a natural experiment which caused quasi-random regional inflation shocks across Russia.

Our results further show that the impact of inflation on credit dollarization is weaker in regions that are financially less integrated with the rest of the Russian Federation-that is to say, regions with a higher share of local banks or local bank branches and regions where banks are more reliant on local funding. In such regions, the negative impact of inflation on the demand for foreign currency loans is partially or fully offset by banks' efforts to locally intermediate the increased supply of foreign currency deposits.

Our contribution to the literature is four-fold. First, we provide new insights into how inflation impacts financial intermediation. Boyd, Levine, and Smith (2001) document a negative relationship between inflation (once it surpasses a certain threshold) and banking development. De Nicoló, Honohan, and Ize (2005) show, also at the country level, that deposit dollarization moderates this adverse effect of inflation as it allows households to keep deposits onshore when they face high inflation. We focus on how the impact of inflation on dollarization depends on banking integration, as predicted by the portfolio theory of financial dollarization (Ize and Levy-Yeyati, 2003). This theory argues that the currency composition of assets and liabilities of risk-averse agents is determined by the risk and return of local currency versus foreign currency assets. Importantly, and in line with our results, the theory suggests that the congruence of the currency composition of assets and liabilities in an economy depends on how open or closed the financial sector of that economy is. 
Second, we complement cross-country studies that examine the relationship between domestic monetary conditions and financial dollarization. Examining aggregate data for forty-six countries for the years 1990-95, Ize and Levy-Yeyati (2003) find that the share of foreign currency deposits is positively related to inflation volatility and negatively to exchange rate volatility. De Nicoló, Honohan, and Ize (2005) examine 100 countries for the period 1990-2001 and confirm the impact of inflation and exchange rate volatility on aggregate deposit dollarization. They also find that high inflation is associated with more dollarization. More recently, Lin and Ye (2013) document that adoption of inflation targeting in emerging market countries results in a decline in dollarization. For emerging Europe, Luca and Petrova (2008) find that the share of foreign currency loans is positively related to interest rate differentials and inflation volatility whereas it is negatively related to exchange rate volatility. Basso, Calvo-Gonzalez, and Jurgilas (2010) confirm these results by examining aggregate credit and deposit dollarization for twenty-four transition countries for the period 2000-06.

We complement this cross-country literature by examining cross-regional variation within one and the same country. An advantage of exploiting within-country variation is that we need not worry that unobserved heterogeneity in economic policies and institutions at the country level cloud the relationship between monetary conditions and dollarization (a risk that is especially high when cross-country data are purely cross-sectional). We alleviate this concern by, first, examining cross-regional variation within the same country context and, second, by using panel data so that we can also exploit time variation.

Third, our results also complement recent studies that use data at the household or bank level to study demand and supply-side drivers of dollarization. On the demand side, Beckmann and Stix (2015) and Brown and Stix (2015) use household survey data from ten Eastern European countries and document that households that expect a domestic currency depreciation are less likely to demand foreign currency loans. On the supply side, Brown and De Haas (2012) document that the currency structure of customer deposits is a crucial driver of loan dollarization. Relatedly, Brown, Kirschenmann, and Ongena (2014) argue that a large share of foreign currency retail loans in Eastern Europe is supply-driven, as banks are eager to match the currency structure of their assets and liabilities. In contrast to these studies, which look at either deposits or loans, we provide a unified analysis of both forms of dollarization based on regional-level bank balance-sheet positions. Our unifying framework explains how in integrated banking markets loan dollarization is largely demand driven whereas it becomes more supply driven in less-integrated markets.

Fourth, this paper also relates to the growing literature on regional inflation disparities within countries and currency unions. Beck, Hubrich, and Marcellino (2009) compare regional inflation differentials in the euro-zone and the USA and show that such differentials are larger and more persistent in the euro-zone. Regional inflation differences in both currency unions are related to structural characteristics of non-labor factor markets rather than labor market frictions or growth dynamics. Nagayasu (2011) and Vaone and Ascari (2012) confirm the persistence of regional inflation differences for Japan and Italy, respectively. We add by documenting how regional inflation leads to the differential use of the common currency by firms and households.

The paper is structured as follows. Section 2 develops a concise theoretical model of the relationship between regional inflation and financial dollarization and uses this model to derive hypotheses for our empirical analysis. Section 3 describes the data and empirical 
strategy. Section 4 then presents our results on the link between regional inflation and dollarization and how this link depends on regional banking integration. Section 5 concludes.

\section{Regional Inflation and Financial Dollarization: Theory}

Theories of financial dollarization have rationalized the use of foreign currency as a medium of payments (currency substitution) and as a medium to store wealth (asset substitution). The currency substitution theory suggests that agents choose the foreign versus domestic currency as a means of payment by trading off the purchasing power risk of domestic currency versus the transaction costs of using foreign currency (Uribe, 1997; Engineer, 2000). ${ }^{1}$ According to the portfolio theory of asset substitution, households' currency choices for bank deposits are driven by the expected real return and real valuation risk on foreign currency versus domestic currency deposit contracts (Ize and Levy-Yeyati, 2003).

In this section, we illustrate how regional inflation can impact the currency choice of depositors and borrowers in a model of asset substitution. We introduce a framework in which savers and borrowers have heterogeneous exchange rate expectations that are influenced by locally observed inflation. ${ }^{2}$ This means that in a region with higher observed inflation, households and firms expect a stronger depreciation of the local currency. Our model also allows us to explore how the relationship between regional inflation and financial dollarization depends on how well regional banking markets are integrated. A region with a fully integrated banking sector can better accommodate a divergence in the regional currency composition of deposit and loans through offsetting positions in the interregional money market. The Appendix presents a more detailed analysis of our model.

\subsection{Model Assumptions}

Consider an economy that is divided into many small regions. In each region $r$ there are $s_{r}$ savers, each endowed with 1 unit of the domestic currency. For simplicity, we assume that in each region there are $b_{r}=s_{r}$ potential borrowers who would like to borrow the equivalent of 1 unit of the domestic currency. There is one bank in each region. This bank offers term deposits from $t=0$ to $t=1$ in domestic and foreign currency at interest rates $i_{d}^{l}$ and $i_{d}^{f}$, respectively. The bank also offers one-period credit in domestic and foreign currency at interest rates $i_{c}^{l}$ and $i_{c}^{f}$, respectively. The transaction costs to the bank of acquiring one unit of deposits are $k_{d}$ and the transaction costs for dispersing one unit of credit are $k_{c}$. We account for potential market power of the bank in each region by assuming it can charge a mark-up $q_{d}$ and $q_{c}$ in the deposit and credit market, respectively. As we assume that the

1 Craig and Waller (2004) endogenize the transaction costs of using foreign currency in a model with network effects. Valev (2010) provides household-level evidence for Bulgaria suggesting that network effects have a stronger influence on currency substitution than variation in individual exchange rate expectations.

2 Models with heterogeneous signals of monetary developments across agents provide such a framework (Phelps, 1970; Lucas, 1972; Morris and Shin, 2002; Myatt and Wallace, 2014). Moreover, recent scapegoat models point to the role of uncertainty about one or more macroeconomic fundamentals and the structural parameters that link fundamentals to the exchange rate. Such uncertainty may lead individuals to overweigh fundamentals that are observable to them when forming exchange rate expectations. See Bacchetta and van Wincoop (2013) for theory and Fratzscher et al. (2015) for empirical evidence. 
markets for local and foreign currency deposits are fully integrated, that is, the bank faces the same potential clients for both currencies, it is consistent to assume that transaction costs and mark-ups are independent of the currency of funds. The same applies to the loan market. We further assume that due to prudential regulation or internal risk management, banks must match the currency structure of their assets and liabilities. For simplicity, we abstract from credit risk.

We assume that banks in all regions have a common exchange rate expectation for $t=1$ which is embedded in the forward rate $e_{m}$. In contrast, we allow exchange rate expectations of savers and borrowers to be heterogeneous. Agents form exchange rate expectations based on the observed market forward rate $e_{m}$ and local consumer price inflation $p_{r}$. Each agent $j$ forms expectations

$$
e_{j}=e_{j}\left(e_{m}, p_{r}\right), \text { whereby } \frac{\partial e_{j}}{\partial e_{m}}, \frac{\partial e_{j}}{\partial p_{r}}>0 .
$$

We use the notation $\Delta e_{m}=\frac{e_{m}-e_{0}}{e_{0}}$ and $\Delta e_{j}=\frac{e_{j}-e_{0}}{e_{0}}$ to denote the expected depreciation of the domestic currency as perceived by the bank and agent $j$, respectively.

\subsection{Regional Inflation and Saving/Borrowing Behavior}

We assume that savers are risk neutral, ${ }^{3}$ so that a saver with the exchange rate expectation $e_{j}$ deposits their endowment in foreign currency if

$$
i_{d}^{l}-i_{d}^{f} \leq \Delta e_{j}
$$

Borrowers have sufficiently high returns on investment so that their participation constraint is met for domestic and foreign currency loans. Borrowers are also risk neutral and thus prefer to borrow in foreign currency if:

$$
i_{c}^{l}-i_{c}^{f} \geq \Delta e_{j}
$$

We define $\gamma_{r}\left(p_{r}, i_{d}^{l}-i_{d}^{f}\right)$ as the share of savers for which Condition (2) holds and $\delta_{r}\left(p_{r}, i_{c}^{l}-i_{c}^{f}\right)$ as the share of borrowers for which Condition (3) holds. As we assume in Equation (1) that expected depreciation by savers and borrowers is increasing in regionally observed inflation we can assert from Conditions (2) and (3) that the supply of (demand for) foreign currency deposits (loans) in a region increases (decreases) ceteris paribus with regional inflation: $\frac{\partial \gamma_{r}}{\partial p_{r}}>0, \frac{\partial \delta_{r}}{\partial p_{r}}<0$.

\subsection{The Role of Banking Integration}

The discussion above suggests that an increase in regional inflation has an opposite impact on the supply and demand for foreign currency funds. For given currency spreads on deposits and loans (the interest rate differential on domestic versus foreign currency funds) the supply of foreign currency deposits increases while the demand for foreign currency loans decreases with an increase in regional inflation. How a regional bank reconciles the

3 We abstract from risk aversion to focus on the role of regional inflation and banking integration. With risk-averse savers and borrowers the currency choice of deposits and loans would not only be determined by interest rate differentials and expected depreciation (inflation) but also by the expected volatility of inflation and the real exchange rate. See Ize and Levy-Yeyati (2003) for a portfolio model with risk-averse investors. 
currency structure of deposits and loans depends crucially on whether regional banking markets are integrated (see the Appendix for details).

If the bank in region $r$ has access to money market funding in domestic and foreign currency, then the currency mismatch in domestic deposits and loans is balanced by opposite positions in the money market. If higher regional inflation increases foreign currency deposits and reduces foreign currency loans, then the bank increases (decreases) its net position in the foreign (domestic) currency money market. The currency spreads on deposits and loans are determined by the money market, and an increase in regional inflation therefore does not lead to any adjustment in deposit or lending rates. Changes in the currency structure of the banks' customer funds are instead fully compensated by opposite interbank positions.

In contrast, if the bank in region $r$ does not have access to the money market, the currency structure of customer deposits and loans must be reconciled through an endogenous change in the currency spreads on deposits and loans. An increase in regional inflation then requires a reduction in the currency spread on deposits and loans to counter the increase in the supply of foreign currency deposits and the decrease in the demand for foreign currency loans.

The reaction of foreign currency deposits and loans to a change in regional inflation (and thus exchange rate expectations) is less divergent under autarky than under integrated banking markets. Whether a bank accommodates the (inflation-induced) change in the currency composition of loan demand and deposit supply more through the deposit market or through the loan market will depend on the relative sensitivity of loan currency composition and deposit currency composition to the currency spread.

To sum up, our model sets out how higher observed inflation in a region serves as a private signal for households about a future depreciation of the domestic currency. For given interest rates households will then be more likely to save in foreign currency. Likewise, if higher observed inflation in a region leads firms to expect a depreciation of the domestic currency, then for given interest rates firms will be less likely to borrow in foreign currency. A further testable model prediction is that the relation between regional inflation and the currency composition of the regional loan volume is stronger in regions dominated by banks that are more integrated with the national or international financial sector.

\section{Data and Methodology}

\subsection{Institutional Background}

The units of our analysis are seventy-one federal 'subjects' of the Russian Federation (referred to henceforth as regions). ${ }^{4}$ For each region we collect quarterly data on consumer

4 There are eighty-three federal subjects in Russia. From our analysis we exclude three autonomous districts (Nenetsk, Hanty-Mansiysk, and Yamalo-Nenetskiy) as the district data are part of consolidated regional data. We also exclude two federal city-regions (Moscow and St. Petersburg) as these are clear outliers in terms of economic structure. Many firms are incorporated in these cities for fiscal reasons but are physically located elsewhere. Corporate lending in Moscow and St. Petersburg is therefore not necessarily extended to local firms. A similar logic applies to deposits as many affluent Russians from the regions are clients of banks in Moscow or St. Petersburg. This again makes the data for these two cities difficult to interpret because saving decisions of these clients are made in their regions while money is deposited in Moscow or St. Petersburg. Finally, due to severe data limitations, we drop the North-Caucasian conflict zones Chechnya, Dagestan, Ingushetia, North Ossetia, Kabardino-Balkaria, Karachay-Cherkessia, and Adygea. This leaves us with seventy-one regions. 
price inflation over the period 2005:Q2 to 2014:Q2 from the Federal State Statistics Service (Rosstat). For the same period, we hand collect regional data on the currency composition of bank deposits and loans from publications of the Central Bank of Russia (CBR).

Throughout our observation period the exchange-rate regime of Russia was constant. ${ }^{5}$ The CBR targeted a dual-currency basket composed of the US dollar (USD) and Euro with respective weights of $55 \%$ and $45 \%$. This dual-currency targeting policy was introduced in 2005 and abandoned only at the end of 2014. The CBR maintained the USD-Euro basket against the Ruble at a targeted level. Since both currencies entered the basket with roughly equal weights, triangular arbitrage dictated that the USD/Ruble and Euro/Ruble exchange rates were determined by the free-floating Euro/USD exchange rate.

\subsection{Data on Regional Inflation}

Our data are particularly well suited for testing the impact of regional inflation on dollarization. To facilitate cross-regional analysis and provide a consistent purchasing power measure, Rosstat has devised a consumer price index (CPI) that tracks monthly price dynamics of a fixed basket of consumer goods and services across all Russian regions. We use this index to calculate for each region and for each quarter a year-on-year (y-o-y) inflation rate and inflation volatility. We define the latter as the standard deviation of monthly inflation in the 12 months before the end of a quarter.

Figure 1 shows the cross-regional dispersion and time-variation in Russian inflation that we exploit in this paper. Individual observations indicate the deviation of the regional y-o-y CPI in a particular quarter from the mean inflation rate for the full country sample over the entire observation period. As we use a uniform consumer goods basket for all regions, regional dispersion does not reflect different weights. By way of comparison, we present regional inflation data for the eurozone (twelve countries) and the USA (twenty-five metropolitan areas).

Figure 1 shows that in Russia, as in the USA and the eurozone, cross-sectional variation in inflation across regions is substantial. For instance, the underlying data show that in the first quarter of 2006 the median regional y-o-y inflation rate in Russia was $14.38 \%$ but ranged between $5.84 \%$ and $20.80 \%$ across regions. Throughout the sample period the difference between the highest and the lowest regional inflation rate in a quarter was on average 14.34 percentage points. ${ }^{6}$

The sample contains three periods in which inflation accelerated-early 2005, mid-2008, and mid-2010 to mid-2011. All three episodes were driven by external factors. The first spike reflects a sharp increase in the price of heating services which coincided with rising oil prices. The second and third spikes were driven by food inflation. World food prices accelerated dramatically in 2007-08 following droughts in several grain-producing countries, the increased

5 While Russia's 2004 capital account liberalization lifted all restrictions on foreign currency transactions by residents and non-residents, there were no dramatic changes in monetary policy during the period we study (though the authorities did react to an overheating economy by raising the policy rate in 2008).

6 This is consistent with a recent analysis of regional price dispersion by Gluschenko (2013) for the period 2001-10. The persistence in regional inflation differences reflects the continuation of administrative price controls, formal restrictions on inter-regional exports and imports, and organized crime that blocks imports in order to maintain local rents. Moreover, Russia's nation-wide infrastructure for the marketing and distribution of consumer goods is still limited, leading to relatively regionalized markets (Gluschenko, 2001). 

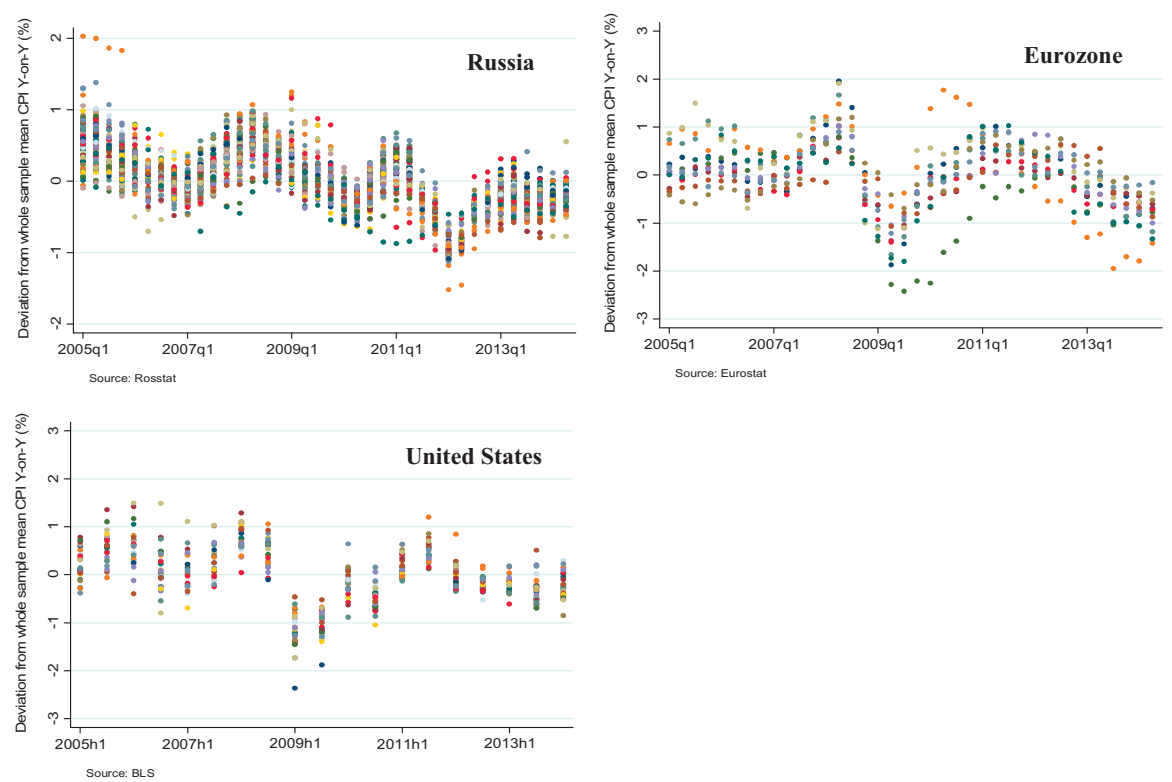

Figure 1. Dynamics of regional inflation dispersion across Russia, the Eurozone, and the USA.

Notes: These graphs compare the development of inflation dispersion across seventy-one Russian regions (top left), twelve Eurozone countries (top right), and twenty-five US urban areas (bottom left). Regional observations measure the deviation from the country-sample mean of the y-o-y CPI. Source: Central Bank of the Russian Federation, US Bureau of Labor Statistics, and Eurostat.

use of bio-fuels and high oil prices which raised transportation and fertilizer costs. The 2010 summer droughts and wildfires across Russia pushed up food prices again in 2011. In Section 4.4, we will exploit exogenous variation in regional inflation due to the 2010 wildfires to assess the causal relationship between inflation and dollarization.

Figure 2 shows geographical "heat maps" of average inflation as well as deposit and credit dollarization across regions. Panel A displays average consumer inflation over the period 2005:Q2 to 2014:Q2. The substantial cross-regional variation in average inflation is again apparent. Importantly, behind these averages also lies substantial within-region variation over time. For instance, in 2014:Q2 consumer price inflation in the Kursk region was 2.3 percentage points higher than in 2004:Q2, while it declined by 28.9 percentage points in Kamchatka over the same period.

\subsection{Data on Financial Dollarization}

We obtain quarterly data on the currency composition of bank deposits and loans from the CBR. The central bank requires all commercial banks to submit detailed information on their quarterly activities by geographical location. These region-specific banking data are classified by client type (households or firms) and by currency denomination (domestic or foreign). This allows us to trace how regional consumer price inflation is associated with the currency denomination of deposits and loans with banks. ${ }^{7}$

7 All banks in Russia offer multi-currency deposits that allow retail customers to easily convert savings between different currencies through automatic teller machines or online accounts. 


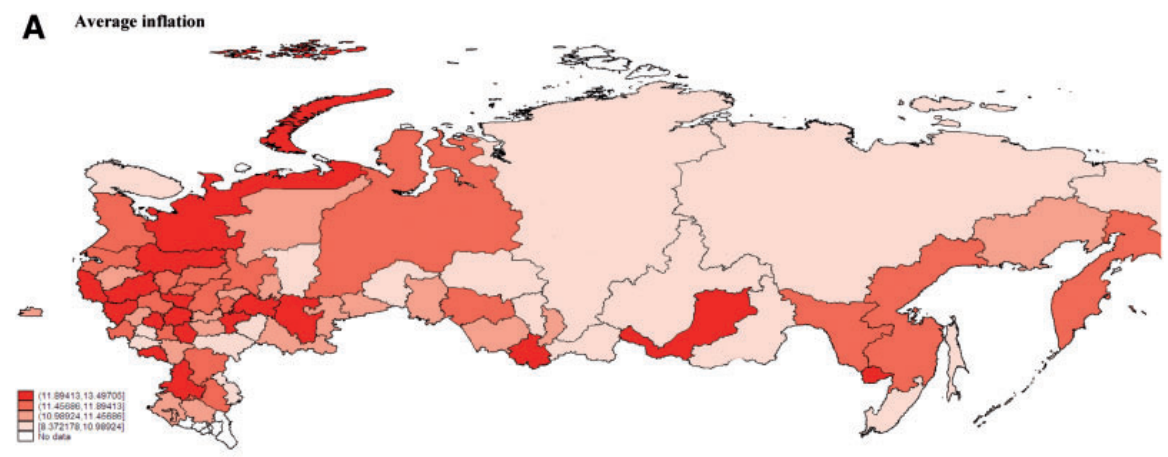

B Average share of FX deposits

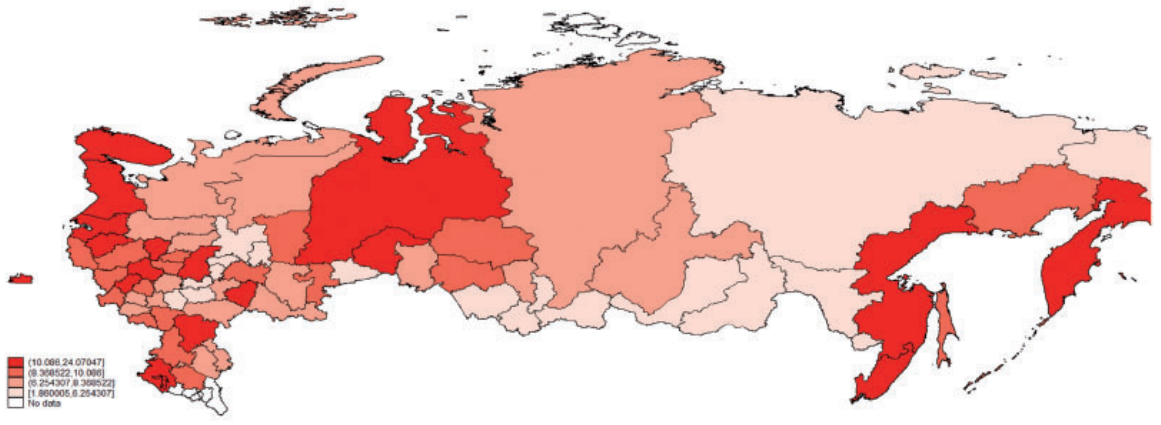

C Average share of FX lending to firms in non-tradable sectors

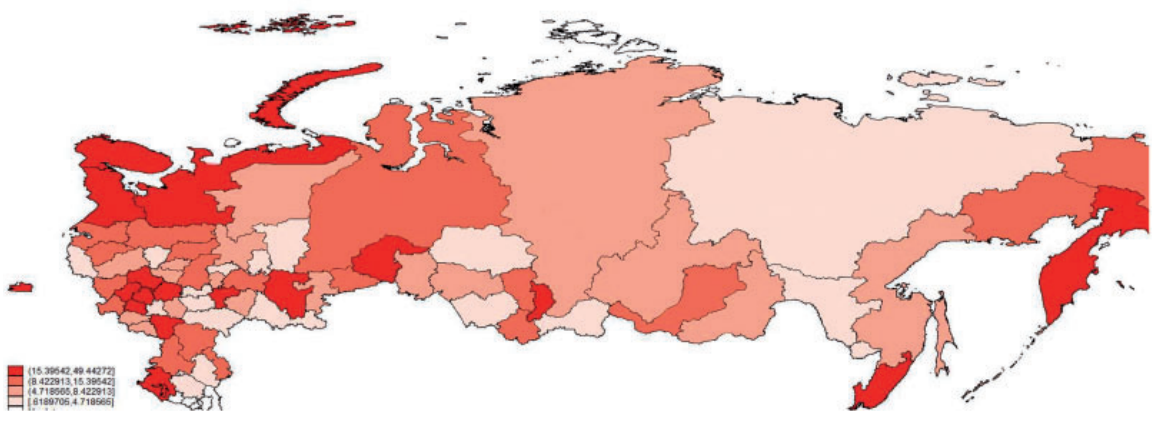

Figure 2. Regional inflation and dollarization across Russia.

Notes: These maps of the Russian regions show average consumer price inflation (upper map); average share of bank deposits denominated in a foreign currency (middle map); and the average share of lending to firms in non-tradable sectors denominated in a foreign currency (lower map). Sample period: Q2 2005-Q2 2014.

Source: Central Bank of the Russian Federation and the Federal State Statistics Service of Russia (Rosstat).

We adjust the volume of foreign currency deposits (reported in Rubles) for changes in exchange rates to disentangle changes in actual stocks from valuation effects. We then use

A competitive deposit market has made conversion costs quite low. According to central bank statistics, the average bid-ask spread for Ruble-USD retail transactions was $1.63 \%$ during the period of our study. 
these quarterly volume data to calculate the stock of household bank deposits by region and currency. Data on deposit volumes for the household sector are available since 2005:Q2 which sets the beginning of our sample period. Our sample ends in 2014:Q2 and we exclude the crisis year 2008:Q3-2009:Q3.

For each region and quarter the variable $\Delta$ Deposit dollarization measures the quarterly change in the share of FX deposits in total household deposits (in percentage points). Panel B of Figure 2 shows the average share of deposits in foreign currency. As with inflation, there is substantial variation in average deposit dollarization across regions. The share of FX deposits also changes substantially within regions over time. For instance, in the Kaliningrad region, deposit dollarization declined by 17.57 percentage points during our sample period.

The variable $\Delta$ Loan dollarization measures the quarterly change in the share of FX credit in total credit to firms in a region (again in percentage points). We again adjust credit in foreign currency (which is reported in Rubles) for quarterly changes in exchange rates to correct for valuation effects. We distinguish between the dollarization of lending to firms in tradable versus non-tradable sectors, using the Jensen and Kletzer (2005) classification. We expect that regional inflation mainly affects the currency composition of firms that base their monetary expectations on locally observed consumer price developments. This should especially be the case for firms in non-tradable sectors whose operations tend to have a much narrower geographical focus.

Panel C of Figure 2 shows the average share of FX loans to Russian firms in nontradable sectors as a share of total bank lending to these firms. We observe again substantial cross-regional variation: the average ratio was $2.36 \%$ in the Saratov region but $49.44 \%$ in the Murmansk region. Within regions there was also strong variation over time. For instance, the proportion of lending to non-tradable firms denominated in FX increased by 15.76 percentage points in the Tula region during our sample period while it declined by 27.17 percentage points in the Tomsk region.

The variable $\Delta$ Mortgage dollarization measures new FX mortgage lending by banks in a region as a percentage of total new mortgage lending by banks in that region. Most Russian mortgages have fixed rather than variable interest rates, making inflation expectations at the time of signing the contract a potentially important determinant of the preferred currency of denomination. FX mortgage lending dried up quickly and completely when the global financial crisis hit Russia toward the end of 2008 (World Bank, 2013, pp. 54-55). Our sample period for mortgage dollarization therefore ends in 2008:Q2. These and all other variables used in the analysis are defined and summarized in Appendix Tables AI and AII. Appendix Table AIII provides a correlation matrix. We winsorize variables at the 1 st and 99 th percentiles.

\subsection{Methodology}

Section 2 highlighted the channel through which regional inflation can affect dollarization. Based on these considerations we estimate the following empirical model:

$$
\Delta \mathrm{FX}_{i t}=\alpha_{t}+\alpha_{i}+\beta_{1} \cdot \Delta \text { Inflation }_{i t-1}+\gamma \cdot X_{i t}+\varepsilon_{i t} .
$$

The dependent variable $\Delta \mathrm{FX}$ it is either the change in the share of FX deposits ( $\Delta$ Deposit dollarization), the change in the share of FX firm loans ( $\Delta$ Loan dollarization), or new FX mortgage lending as a percentage of total new mortgage lending ( $\Delta$ Mortgage dollarization) 
in region $i$ in quarter $t$. Our main explanatory variable is the change in regional y-o-y inflation $\Delta$ Inflation $_{i t-1}$ lagged by one quarter. ${ }^{8}$

Realized exchange rate volatility and interest rates are homogenous across regions and absorbed by time-fixed effects $\alpha_{t}$. The region-fixed effects $\alpha_{i}$ account for (time-invariant) differences in the risk aversion of households across regions, as well as the persistent part of cross-regional inflation differentials. Such persistent differentials can reflect different income levels (the Balassa-Samuelson effect) as well as frictions in factor markets (Beck, Hubrich, and Marcellino, 2009). We estimate all regression specifications using robust standard errors clustered by region to control for possible residual correlation across time for a given region.

The vector $X_{i t}$ captures time-varying regional characteristics which may simultaneously drive changes in regional inflation and dollarization. According to the literature on the determinants of regional inflation these could include changes in economic structure and/or changes in local factor market frictions. We therefore include trade openness (quarterly growth of regional trade (imports plus exports) with foreign countries); the value of tradable goods (quarterly growth of the regional value added of the manufacturing and commodity-extraction industries); and the value of non-tradables (quarterly growth of the regional value added of the construction, electricity generation, services, retail, and wholesale trade industries) as control variables in our empirical model.

Regional inflation and financial dollarization might also be correlated because both are impacted by local fiscal policy which differs across regions and over time. For example, De Gregorio, Giovannini, and Wolf (1994) demonstrate that public expenditures can induce an increase in the relative price of non-tradables. Fiscal transfers to specific household types may also alter the currency denomination of their savings. To control for these effects, we include the y-o-y growth of regional government spending as an additional covariate in $X_{i t}$.

$X_{i t}$ also contains two dummy variables to account for the entry and exit of banks. These dummies are switched on in a region-quarter if there is an increase (Bank entry) or decrease (Bank exit) in the number of banks in a quarter or in the previous three quarters (thus allowing a bank entry or exit to affect loan dollarization with a slight lag). Through these dummies we control for sudden changes in the regional banking landscape which may lead to one-off "jumps" in dollarization on either the asset or liability side of regional banks.

\subsection{Banking Integration}

Russia's regions vary considerably with respect to how strongly regional banks are integrated with the rest of the domestic banking sector. We employ three indicators to measure (the lack of) regional banking integration. First, we calculate the share of locally incorporated banks (Proportion local banks ${ }_{i}$ ) in the total number of banks in a region (i.e. local and inter-regional banks). Second, we take the share of branches of locally incorporated banks (Proportion local bank branches ${ }_{i}$ ) in the total number of bank branches in a region. Third, we compute the share of a region's bank liabilities that are on the balance sheet of

8 The portfolio theory (Ize and Levy-Yeyati, 2003) suggests that inflation volatility rather than inflation levels should impact these regional dollarization variables. In robustness tests (presented in Appendix Table AIV) we add a measure of inflation volatility to our main specification. This does not alter our main findings. Moreover, when we use GMM to estimate our model in levels rather than first differences our results are also qualitatively unchanged (Appendix Table AV). 
locally incorporated banks (Proportion local bank liabilities ${ }_{i}$ ). These indicators are timeinvariant and measured prior to our observation period to mitigate endogeneity concerns. ${ }^{9}$

On average, nearly one-third of the banks in any region in Russia are local and operate in that region only. However, the share of local banks varies between 0 and $73 \%$ (see Appendix Table AII). The share of branches operated by local banks is $9 \%$ on average but again this varies from 0 to $50 \%$ across regions. Therefore, only nation-wide banks operate in some regions whereas in other regions most banks and bank branches are local. This variation is also reflected in the proportion of bank liabilities that are held by local banks. This proportion varies between 0 and $94 \%$.

We exploit this regional heterogeneity in banking integration to examine whether the impact of regional inflation on financial dollarization depends on how well integrated a banking sector is. The reasoning is that in regions with less integrated banking sectors, banks cannot allocate FX funds across regions, neither via external markets nor through internal capital markets. ${ }^{10}$ This means that if banks aim to avoid currency mismatches on their balance sheet, local FX deposits need to be intermediated into local FX credit (see Calvo, 2001; Brown and De Haas, 2012). ${ }^{11}$ In contrast, when banks are regionally integrated the local supply and demand of FX funds need not coincide. In regions with integrated banking systems, households and firms can therefore independently adjust their currency portfolio to changes in regional inflation.

In sum, we expect that the impact of inflation across Russian regions on the dollarization of household deposits is less positive and/or the impact of inflation on credit dollarization is less negative in regions with closed bank sectors. We empirically test this prediction by augmenting our baseline specification with an interaction term of inflation with one of three measures of regional banking integration. Equation (5) captures our augmented empirical model in which $\Delta$ Inflation $_{i, t-1}{ }^{*}$ Bank_Local $_{i}$ is the interaction term of interest. In our estimations of credit dollarization we expect the coefficient of the interaction term to be positive: the impact of inflation on credit dollarization will be less negative in regions with non-integrated banking sectors. ${ }^{12}$ In contrast, in our estimation of deposit dollarization we expect the interaction term to be insignificant.

$$
\Delta \mathrm{FX}_{i t}=\alpha_{t}+\alpha_{i}+\beta_{1} \cdot \Delta \operatorname{Inflation}_{i t-1}+\beta_{2} \cdot \Delta \operatorname{Inflation}_{i t-1} \cdot \text { BankLocal }_{i}+\gamma \cdot X_{i t}+\varepsilon_{i t} .
$$

\section{Results}

\subsection{Inflation and Dollarization-Baseline Results}

We report our baseline results in Table I. As dependent variables, we use the change in the dollarization of households' deposits (Column 1) and of firm loans (Columns 2-4). We split up firm loans into loans to firms in non-tradable sectors (Column 3) versus tradable sectors

9 Proportion local bank branches $s_{i}$ is measured for 2012 due to a lack of earlier data.

10 Evidence from the USA (Morgan, Rime, and Strahan, 2004; Loutskina and Strahan, 2015); Japan (Imai and Takarabe, 2011); and the Netherlands (Cremers, Huang, and Sautner, 2011) indicates that banks reallocate funds across regions within one and the same country.

11 In the asset substitution model of Ize and Levy-Yeyati (2003), the minimum variance portfolio of local households is then the only possible financial equilibrium in a closed economy.

12 The region-fixed effects $a_{i}$ absorb the main terms of the cross-sectional measures of banking integration. 
Table I. Regional inflation and financial dollarization across Russia

This table shows OLS regressions to estimate the impact of the change in regional consumer price inflation on the change in dollarization across Russia's regions. Sample period: Q2 2005Q2 2008 and Q4 2009-02 2014. Robust standard errors are clustered by region and $t$-statistics appear in parentheses. ${ }^{* *}, * *$, and ${ }^{*}$ correspond to the $1 \%, 5 \%$, and $10 \%$ level of significance, respectively. Table Al in the Appendix contains all variable definitions.

\begin{tabular}{|c|c|c|c|c|}
\hline & \multirow{2}{*}{$\begin{array}{c}\Delta \text { Deposit } \\
\text { dollarization }\end{array}$} & \multicolumn{3}{|c|}{$\Delta$ Loan dollarization } \\
\hline & & $\begin{array}{c}\text { Firms } \\
\text { [2] }\end{array}$ & $\begin{array}{c}\text { Firms: } \\
\text { non-tradables } \\
{[3]}\end{array}$ & $\begin{array}{c}\text { Firms: } \\
\text { Tradables } \\
{[4]}\end{array}$ \\
\hline$\Delta$ Inflation & $\begin{array}{l}0.011 * * * \\
(3.526)\end{array}$ & $\begin{array}{c}-0.029^{*} \\
(1.895)\end{array}$ & $\begin{array}{c}-0.055^{* *} \\
(2.123)\end{array}$ & $\begin{array}{c}-0.003 \\
(0.161)\end{array}$ \\
\hline Growth trade openness & $\begin{array}{l}0.001^{* *} \\
(2.053)\end{array}$ & $\begin{array}{l}0.003^{* *} \\
(2.085)\end{array}$ & $\begin{array}{c}-0.000 \\
(0.134)\end{array}$ & $\begin{array}{c}0.002 \\
(0.911)\end{array}$ \\
\hline Growth value tradables & $\begin{array}{c}-0.000 \\
(0.517)\end{array}$ & $\begin{array}{c}0.001 \\
(0.242)\end{array}$ & $\begin{array}{c}0.007 \\
(1.312)\end{array}$ & $\begin{array}{c}-0.001 \\
(0.027)\end{array}$ \\
\hline Growth value non-tradables & $\begin{array}{c}-0.000 \\
(0.156)\end{array}$ & $\begin{array}{c}0.002 \\
(0.252)\end{array}$ & $\begin{array}{c}0.005 \\
(0.572)\end{array}$ & $\begin{array}{c}-0.005 \\
(0.543)\end{array}$ \\
\hline Growth government expenditures & $\begin{array}{r}-0.002^{*} \\
(1.883)\end{array}$ & $\begin{array}{c}0.002 \\
(0.441)\end{array}$ & $\begin{array}{c}0.002 \\
(0.380)\end{array}$ & $\begin{array}{c}-0.001 \\
(0.264)\end{array}$ \\
\hline Region FE & Yes & Yes & Yes & Yes \\
\hline Time FE & Yes & Yes & Yes & Yes \\
\hline Bank entry-exit dummies & Yes & Yes & Yes & Yes \\
\hline Observations & 2,258 & 2,259 & 2,258 & 2,258 \\
\hline Regions & 71 & 71 & 71 & 71 \\
\hline$R$-squared & 0.69 & 0.14 & 0.13 & 0.15 \\
\hline
\end{tabular}

(Column 4). All specifications include region and time (i.e., quarter) fixed effects, dummy variables that control for the entry and exit of banks over the previous year, and our standard set of time-varying regional covariates.

The key message that emanates from Table I is that higher regional inflation is associated with more foreign currency deposits of households and less foreign currency loans to firms, especially to firms in non-tradable sectors. The impact of inflation on dollarization is substantial. A one standard deviation (s.d.) increase in the change of regional inflation is associated with a $0.1 \mathrm{s.d}$. increase in the change of deposit dollarization in the next quarter and a 0.1 s.d. decrease in the change of loan dollarization to non-tradable firms. ${ }^{13}$ Column 4 does not show an effect of inflation on the currency denomination of loans to firms in

13 A comparison of the $R^{2}$ of the deposit and loan regressions suggests that our explanatory variables explain more of the variation in deposit dollarization than in loan dollarization. A further analysis of the $R^{2}$ s (in specifications with and without region- and time-fixed effects) indicates that the difference in explanatory power between the deposit and loan regressions mainly reflects the power of the fixed effects. 
tradables sectors. This confirms our conjecture that regional inflation affects the monetary expectations of firms in tradable sectors to a lesser extent. ${ }^{14}$

\subsection{The Role of Banking Integration}

In Table II, we analyze how the relationship between regional inflation and dollarization is affected by the local banking structure. The results in Columns 1-3 suggest that the impact of inflation on deposit dollarization is independent of how integrated the local banking sector is. The interaction terms $\Delta$ Inflation *Proportion local banks (Column 1); $\Delta$ Inflation *Proportion local bank branches (Column 2); and $\Delta$ Inflation *Proportion local bank liabilities (Column 3) are weak both in terms of statistical significance and economic magnitude.

In Columns 4-12, we examine the impact of banking sector integration on firm loan dollarization. We expect that in regions with less-integrated banks higher inflation-and the resulting larger FX deposit base-partially offsets the negative direct effect of inflation on credit dollarization. The results in Columns 4-9 show exactly this: The positive and mostly significant interaction terms for $\Delta$ Inflation*Proportion local banks; $\Delta$ Inflation *Proportion local bank branches; and $\Delta$ Inflation *Proportion local bank liabilities, together with the negative main effect of $\Delta$ Inflation, suggest that the negative impact of inflation on firm loan dollarization is weaker in regions with non-integrated banking sectors. ${ }^{15}$ Again, we find no such effects for lending to firms in tradable sectors (Columns 10-12).

Banking integration has a sizeable impact on the relation between inflation and credit dollarization. For instance, the estimates in Column 8 indicate that while the direct impact of higher inflation on loan dollarization is strongly negative for firms in non-tradable sectors, this effect becomes smaller and eventually even positive in (very) closed regional banking markets. The overall impact of inflation on dollarization turns positive when $37 \%$ or more of all bank branches are owned by out-of-region banks. This is in line with anecdotal evidence that suggests that Russian banks that experience an increase in FX deposit inflows react by extending more loans in FX to borrowers in non-tradable sectors. ${ }^{16}$ While banks could in principle place FX deposits in their correspondent account at the central bank or in the interbank market, they would have to forego a substantial amount of interest income.

14 This difference between firms in tradable and non-tradable sectors is statistically significant. When we pool the observations used in Columns 3 and 4 and run a single regression that contains a Non-tradable dummy and an interaction term between this dummy and the Inflation variable, then the coefficient for this interaction term is negative and statistically significant at the $1 \%$ level.

15 We also estimate a specification where we define local banks as domestic (as opposed to foreign-owned) banks. We find a positive but imprecisely estimated interaction between inflation and the share of domestic banks, suggesting that what matters is whether a region's banking sector is integrated with other Russian regions rather than with the rest of the world.

16 The Russian business press regularly highlights this phenomenon (e.g., http://www.gazeta.ru/busi ness/2014/10/30/6283285.shtml) and stresses that banks that experience an influx of FX deposits allocate part of this new FX funding to businesses in non-tradable sectors that may not have a natural hedge (unlike these banks' regular FX borrowers such as large exporters with guaranteed FX contracts). 


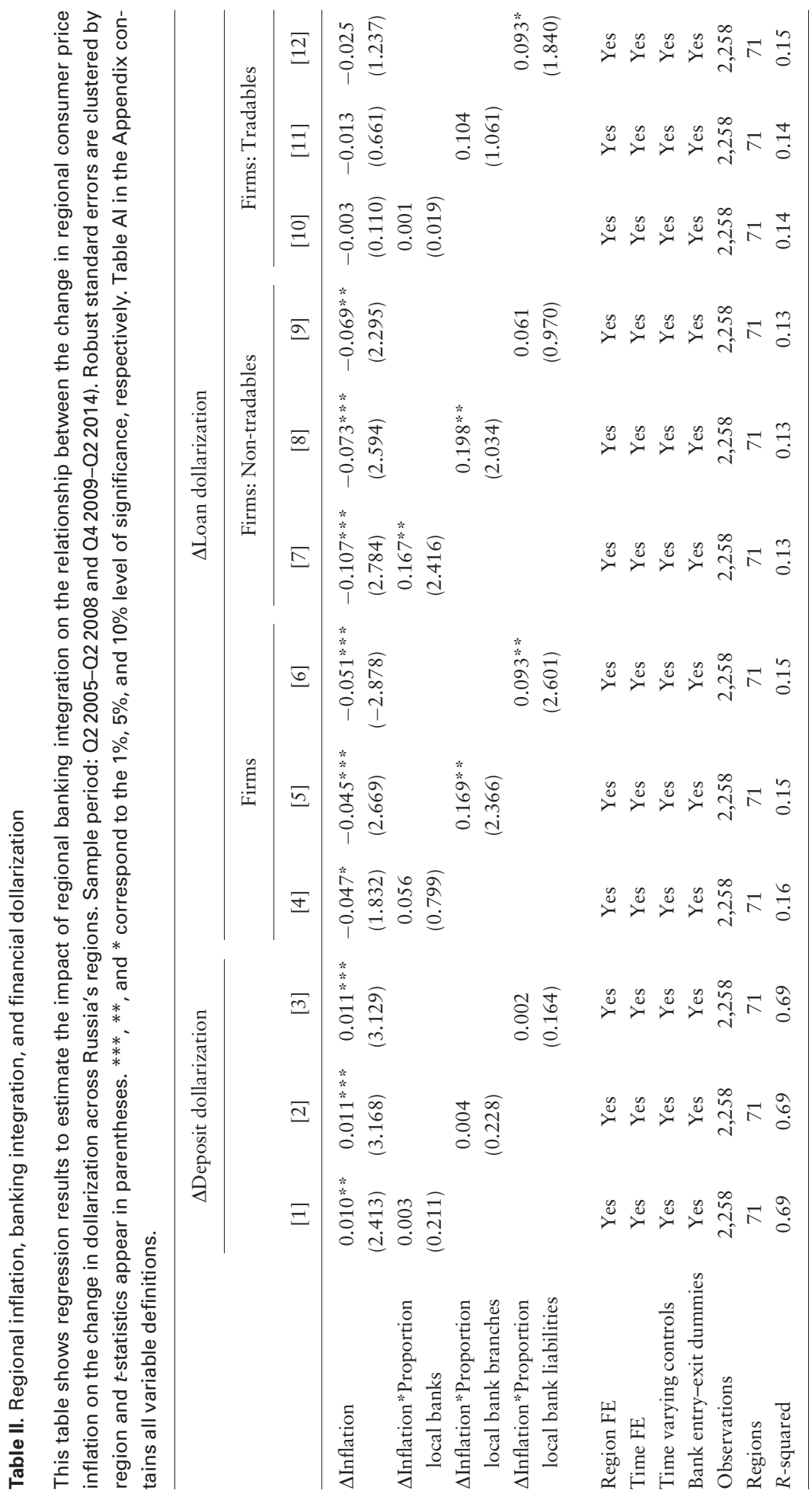


Table III. Regional inflation and mortgage dollarization

This table shows regression results to estimate the impact of the change in regional consumer price inflation on the change in mortgage dollarization across Russia's regions. Sample period: Q2 2005-02 2008. Robust standard errors are clustered by region and $t$-statistics appear in parentheses. ${ }^{* * *},{ }^{* *}$, and ${ }^{*}$ correspond to the $1 \%, 5 \%$, and $10 \%$ level of significance, respectively. Table Al in the Appendix contains all variable definitions.

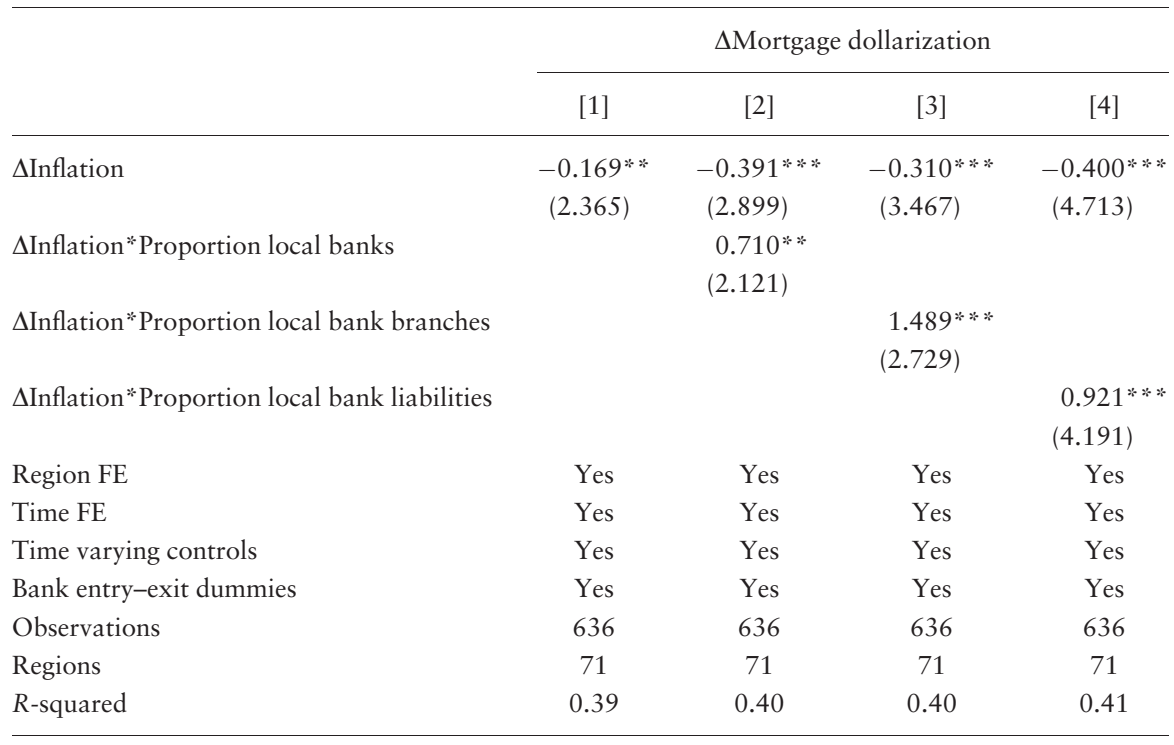

\subsection{Mortgage Dollarization and Further Robustness Tests}

In Table III, we replicate our analysis to assess the impact of regional inflation on the dollarization of mortgage loans. ${ }^{17}$ Because the market for FX mortgages dried up when the global financial crisis hit Russia in 2008, our sample period is significantly shorter here. We nevertheless fully replicate our earlier results for lending to firms in the non-tradable sector.

All four columns show a strong negative effect of regional inflation on the share of new mortgages extended in FX. This impact is again substantial: a one s.d. increase in regional year-on-year inflation is associated with a 0.1 s.d. decrease in mortgage dollarization in the next quarter. Columns $2-4$ once more show that in regions with relatively closed banking systems, the negative impact of inflation on mortgage dollarization is smaller. In these lessintegrated regions, banks have to locally intermediate the increased supply of FX deposits when inflation rises. This supply effect counteracts the effect of inflation on households' demand for FX mortgages.

Table IV presents various robustness tests. We start with a number of replications of our baseline estimates for the impact of inflation on deposit dollarization as reported in Column 1 of Table I. Column 1 of Table IV excludes the standard set of regional timevarying covariates while Column 2 excludes the dummy variables that control for the entry and exit of regional and multiregional banks over the previous year. These robustness tests yield very similar estimates for $\Delta$ Inflation as those in the baseline regressions, both in terms

17 The average maturity of Ruble (FX) mortgages in our dataset is 16.3 (14.5) years. 


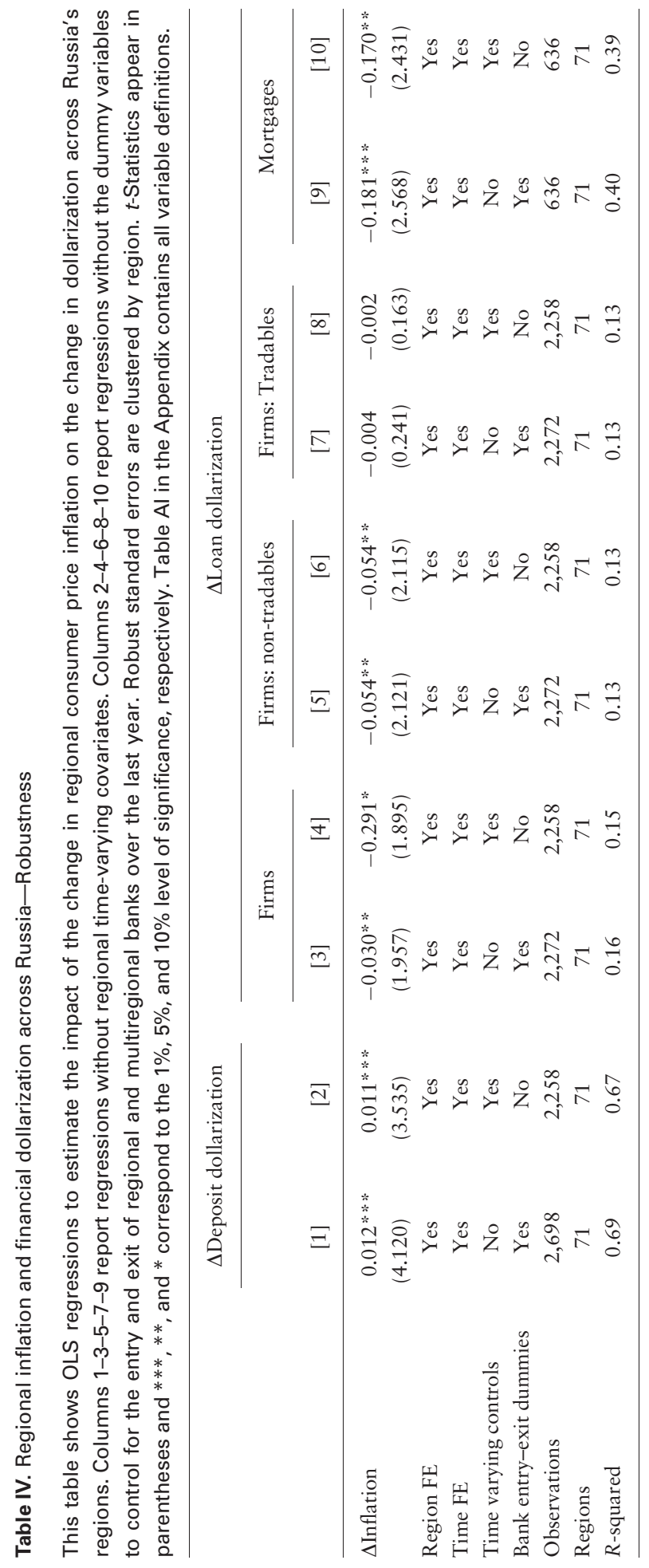




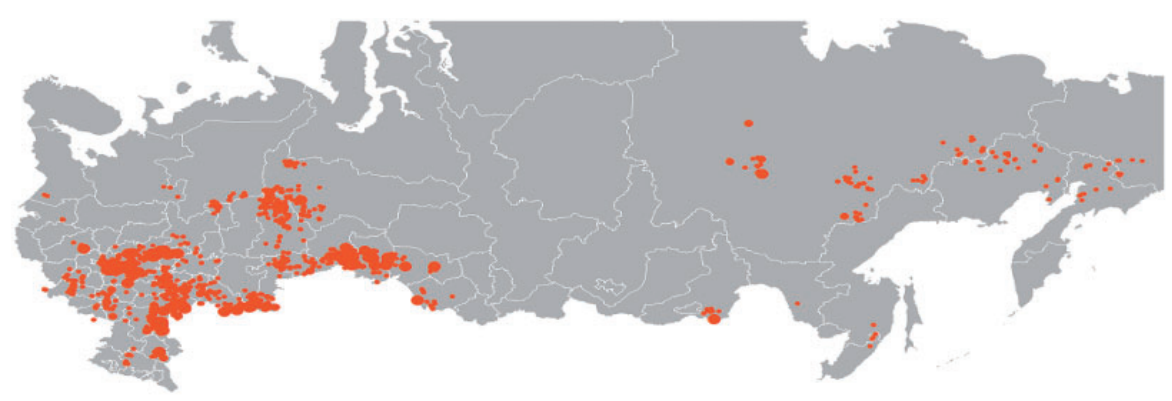

Figure 3. Wildfire intensity across Russia (2010).

Notes: This heat map shows local variation in the intensity of drought-related Russian wildfires in the second half of 2010. Dots show areas where fires occurred and the dot size is proportional to the size of the affected area.

Source: http://fires.kosmosnimki.ru/.

of economic magnitude and statistical significance. In Columns 3-10 we replicate these robustness tests for the baseline estimate of the effect of inflation on firm and mortgage dollarization. Here as well our results are robust to changes in the control variables.

\subsection{Inflation Shocks and Dollarization: A Natural Experiment}

This section exploits a natural experiment to identify the causal impact of inflation shocks on financial dollarization. The setting is the well-documented case of Russia's disastrous wildfires in 2010. ${ }^{18}$ An unprecedented drought and heat wave-Russia experienced the hottest summer since 1936-caused wildfires to swipe across the country between the end of July and the beginning of September. Schultz and Libman (2015) show that the spatial distribution of these fires was quasi-random as it mainly reflected idiosyncratic differences in local temperatures and wind patterns. Figure 3 provides a heat map of the regional variation in wildfire intensity. The dots show areas where fires occurred and the size of each dot is proportional to the surface of the affected area.

The economic impact of the wildfires was severe: aggregate damage was estimated at $1.4 \%$ of GDP. More than half a million hectares of land was burned and about a third of the country's wheat crop was destroyed. The combination of fires and drought also led to the failure of other food crops such as beets, potatoes, and corn. Bad corn harvests also had gradual knock-on effects on meat prices. As local food-supply chains became increasingly strained, food inflation rose dramatically in many affected regions. This moderated the post-harvest slowdown of inflation due to lower prices of fruits and vegetables that is typically observed over summer in Russia. Both the Russian and foreign press raised concerns that the droughts and fires would gradually drive up inflation with a lag of about a year. ${ }^{19}$

Lazarev et al. (2014) also use this natural disaster to exploit variation in exposure to wildfires. Other recent papers that use weather shocks and natural disasters as sources of exogenous variation include Miguel, Satyanath, and Sergenti (2004); Burke and Leigh (2010); and Brückner and Ciccone (2011).

19 See http://bankir.ru/publikacii/20100819/zasyha-i-pojari-privedyt-k-yskoreniu-inflyacii-6021145/; http://www.lesechos.fr/05/08/2010/lesechos.fr/020707975984_moscou-confronte-a-un-risque-infla tionniste-accru.htm and http://rbcdaily.ru/economy/562949992287577. 


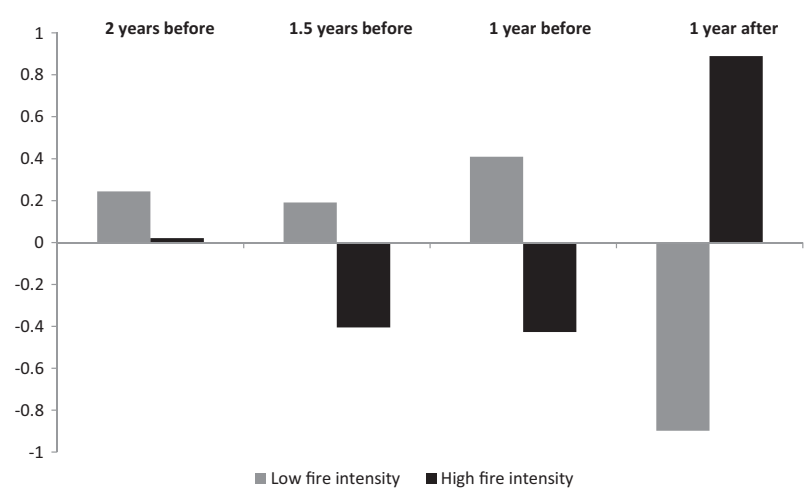

Figure 4. Wildfire intensity and regional inflation: difference-in-differences.

Notes: This bar chart compares average inflation in Russian regions with above-median (high) and below-median (low) wildfire intensity in the years before and the year after the wildfires. "2 years before" refers to Q42008-042009; "1.5 years before" to Q2 2009-02 2010; "1 year before" to Q4 2009-Q4 2010; and "1 year after" to Q4 2010-Q4 2011. The vertical axis indicates the percentage point difference between, on the one hand, average inflation in low and high-fire intensity regions and, on the other hand, average Russian inflation. This percentage point difference between both types of regions is statistically insignificant in the three periods before the wildfires ( $t$-stats are 0.294 , 0.758 , and 0.893 , respectively) and statistically significant after the wildfires ( $t$-stat $=2.233$ ). A formal difference-in-differences regression of the change in inflation (in the year before versus the year after the wildfires) between high and low wildfire regions gives a $p$-value of 0.035 .

Against this background, we use the 2010 fires as an exogenous driver of subsequent regional inflation. Our regional instrument Wildfires is the ratio of the area covered by fire to the number of fires, that is, the average spread of a wildfire in 2010 in region $i^{20}$ A higher value indicates that once a wildfire occurred it was only extinguished at a late stage, causing more damage (Schultz and Libman, 2015). In the first stage of our crosssectional IVs framework, we use 2010 Wildfires to predict regional inflation. The second stage then analyzes how the exogenous component of regional inflation-as determined by wildfire exposure-impacts financial dollarization. The exclusion restriction is that wildfires only affect regional dollarization patterns through their impact on local inflation, which seems a reasonable assumption.

Figure 4 provides a first insight into the relationship between regional wildfire intensity (our instrument) and subsequent regional inflation. The bar chart compares regions with below and above median wildfire intensity and depicts y-o-y inflation for two years, 1.5 years and one year before the wildfires as well as y-o-y inflation over 2010:Q4-2011:Q4 (the year after the wildfires). Each bar measures relative inflation: the difference (in percentage points) between average regional inflation and national inflation.

The three sets of bars on the left of this visual difference-in-differences analysis show that before the onset of the wildfires, there was no significant difference between regions that would subsequently be heavily affected by the wildfires and those that would not.

20 Our data source is Rosstat and, in line with Schultz and Libman (2015), we use wildfire data for the year 2010 as a whole. There were only few fires in the first half of 2010 while about $70 \%$ (30\%) of the fires occurred in the third (fourth) quarter. Using data for these quarters individually or jointly does not affect our results. 


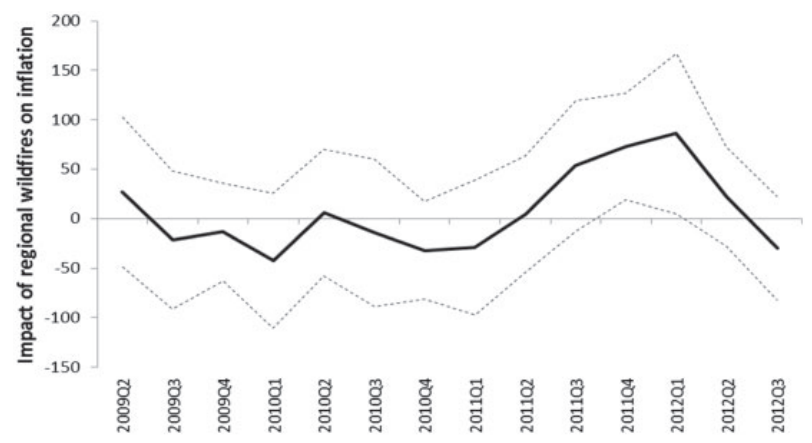

Figure 5. Wildfire intensity and regional inflation: visualization of first-stage IV.

Notes: This graph shows estimated coefficients (solid line) and a 95\% confidence interval (dotted lines) based on repeat cross-sectional regressions in which quarterly regional inflation is explained by regional wildfire intensity in 2010 .

In the former group, inflation was consistently slightly below the national average (the black bars) while in the latter it was slightly above average (the gray bars). The difference between both bars is never statistically significant: the $t$-stats are $0.29,0.76$, and 0.89 for the three "before" periods, respectively. These $t$-stats therefore confirm that before the wildfires, inflation trends in regions that would be beset by these fires developed in parallel to inflation trends in regions where few or no wildfires would take place.

This picture changes dramatically in the year after the wildfires (right side). The average inflation in regions that had not been exposed much to the wildfires is now almost one percentage point below the country average (gray bar). In sharp contrast, average inflation in heavily affected regions is almost one percentage point above the country average (black bar). The difference between both sets of regions is now highly significant ( $t$-stat: 2.233). Figure 4 therefore shows that regional variation in wildfire intensity is strongly associated with diverging regional inflation developments in the subsequent year. In affected regions, spiking food prices had a strong positive effect on overall inflation.

We proceed by more formally assessing the first-stage relationship between regional wild-fire intensity and subsequent inflation. To do so, we repeatedly run cross-sectional regressions for individual quarters, in each case instrumenting y-o-y inflation with wildfire intensity in 2010. We do this for the quarters in the year before the wildfires (2009:Q2 to 2010:Q2), during the wildfires (2010:Q3 and Q4), and various quarters after the wildfires had died down and their impact was working through the food chain into local prices (2011:Q1 to 2012:Q3). Note that we do not expect any impact of the wildfires on prior inflation so that the estimates for the pre-period 2009:Q2 to 2010:Q2 amount to a placebo test.

Figure 5 shows the coefficients that result from these repeated cross-sectional first-stage regressions. As expected, and reassuringly, there is no impact of wildfire intensity on regional inflation before or concurrent with the wildfires. However, in line with a gradual pass through of higher food prices into regional inflation, we observe a strong spike in inflation about a year after the fires. This wildfire-induced spike starts in 2011:Q3 and lasts until the first quarter of 2012. After that, the inflationary impact of the wildfire shock fizzles out. 
Table V. Regional inflation and financial dollarization across Russia: cross-sectional IV results

This table shows cross-sectional IV regressions to estimate the impact of the change in regional consumer price inflation, instrumented by regional wildfire intensity, on the change in dollarization across Russia's regions. The first panel shows the first-stage results and the subsequent three panels show the second-stage results. Robust standard errors are clustered by region. $t$-statistics appear in parentheses and $*^{* *},{ }^{*}$, and ${ }^{*}$ correspond to the $1 \%, 5 \%$, and $10 \%$ level of significance, respectively. Table $\mathrm{Al}$ in the Appendix contains all variable definitions. Constants included but not shown. Regional controls are included in both IV stages.

\begin{tabular}{|c|c|c|c|c|c|c|}
\hline & \multicolumn{2}{|c|}{ Period I } & \multicolumn{2}{|c|}{ Period II } & \multicolumn{2}{|c|}{ Period III } \\
\hline & Q2 2011 & Q3 2011 & Q4 2011 & Q1 2012 & Q2 2012 & Q3 2012 \\
\hline \multicolumn{7}{|c|}{ First stage: $\Delta$ Inflation } \\
\hline & [1] & [2] & [3] & [4] & [5] & [6] \\
\hline Wildfires & $\begin{array}{c}4.562 \\
(0.155)\end{array}$ & $\begin{array}{c}53.362 \\
(1.612)\end{array}$ & $\begin{array}{l}72.903 * * * \\
(2.701)\end{array}$ & $\begin{array}{l}86.107^{* * *} \\
(2.123)\end{array}$ & $\begin{array}{c}22.317 \\
(0.894)\end{array}$ & $\begin{array}{r}-29.893 \\
(1.142)\end{array}$ \\
\hline$R$-squared & 0.08 & 0.25 & 0.47 & 0.30 & 0.18 & 0.09 \\
\hline$F$-stat & 0.50 & 3.49 & 15.33 & 10.18 & 4.90 & 1.31 \\
\hline
\end{tabular}

Second stage: $\Delta$ Deposit dollarization

\begin{tabular}{ccccccc}
\hline & {$[1]$} & {$[2]$} & {$[3]$} & {$[4]$} & {$[5]$} & {$[6]$} \\
\hline \multirow{2}{*}{ Inflation } & -0.053 & 0.400 & 0.082 & $0.049^{* *}$ & $0.057^{* *}$ & -0.058 \\
& $(0.803)$ & $(0.985)$ & $(1.312)$ & $(2.031)$ & $(1.945)$ & $(0.683)$ \\
\multirow{2}{*}{$R$-squared } & 0.26 & 0.48 & 0.25 & 0.12 & 0.06 & 0.04 \\
\hline
\end{tabular}

Second stage: $\Delta$ Loan dollarization (firms)

\begin{tabular}{ccccccc}
\hline & {$[1]$} & {$[2]$} & {$[3]$} & {$[4]$} & {$[5]$} & {$[6]$} \\
\hline \multirow{2}{*}{ Inflation } & -0.050 & 1.433 & -0.447 & $-0.327 * *$ & -0.101 & -0.001 \\
& $(0.111)$ & $(0.919)$ & $(1.361)$ & $(2.313)$ & $(0.835)$ & $(0.002)$ \\
\multirow{2}{*}{$R$-squared } & 0.01 & 0.24 & 0.35 & 0.10 & 0.01 & 0.04 \\
\hline
\end{tabular}

Second stage: $\Delta$ Loan dollarization (non-tradable firms)

\begin{tabular}{ccccccc}
\hline & {$[1]$} & {$[2]$} & {$[3]$} & {$[4]$} & {$[5]$} & {$[6]$} \\
\hline \multirow{2}{*}{ Inflation } & -0.661 & 1.963 & $-1.084^{* *}$ & $-0.559^{* * *}$ & $-0.227^{*}$ & 0.083 \\
& $(1.011)$ & $(0.982)$ & $(1.983)$ & $(2.611)$ & $(1.663)$ & $(0.291)$ \\
\multirow{2}{*}{$R$-squared } & 0.44 & 0.23 & 0.13 & 0.04 & 0.10 & 0.01 \\
\hline
\end{tabular}

The top panel of Table $\mathrm{V}$ repeats these first-stage results. Regional wildfire intensity leads to a significant peak in regional inflation in 2011:Q4 to 2012:Q1 (Period II) but not before (Period I) or after (Period III). The F-statistic in Period II is between 10 and 15, suggesting that Wildfires is a strong instrument to explain regional inflation in these quarters (though not in the previous or later periods).

The subsequent three panels of Table V show the second-stage results. In line with our previous results, we find that exogenous inflation shocks have a positive impact on regional 
deposit dollarization and a negative impact on the regional dollarization of corporate lending, in particular to firms in non-tradable sectors. ${ }^{21}$

\subsection{Integration and Dollarization: Bank-Level Evidence}

Our regional-level results in Section 4.2 indicate that banks that are less integrated into nationwide money markets are more likely to channel inflows of foreign currency deposits (e.g. due to high regional inflation) into foreign currency loans. Existing banklevel evidence supports this finding by documenting that the dollarization of bank loans is strongly related to the dollarization of bank funding (Brown and De Haas, 2012; Brown, Kirschenmann, and Ongena, 2014). However, these existing bank-level studies do not examine to what extent the correlation between bank funding and bank lending-or the open foreign currency position toward customers-depends on the access of the bank to wholesale and capital markets. In this section, we provide new evidence on this topic.

Our analysis is based on hand-collected data from the annual financial statements of 930 Russian banks for the years 2010-11. ${ }^{22}$ Measured by total assets these banks covered $98 \%$ of the Russian banking sector in 2010 . The data include the currency composition of all bank balance sheet positions, that is we know which volume of customer deposits and loans, interbank deposits and loans, as well as financial investments and capital market debt are denominated in a foreign or the local currency. Based on these data we calculate the Open FX position of each bank toward its customers as the volume of FX denominated loans minus the volume of FX denominated deposits, divided by total bank assets.

Figure 6 relates this open FX position vis-à-vis customers to the Wholesale assets (interbank assets plus financial investments as a share of total assets) and Wholesale liabilities (interbank liabilities plus capital market debt as a share of total assets) of each bank. On average, Russian banks have a (short) open FX position toward their customers of $-3.7 \%$ of their balance sheet. However, as Figure 6 reveals, the Open FX position ranges from below $-20 \%$ (short FX position) to over 20\% (long FX position). Figure 6 also shows that banks with a long FX position toward their clients (more FX loans than FX deposits) tend to hold fewer wholesale assets (Panel A) and more wholesale liabilities (Panel B). Linear multiple regressions controlling for bank size and bank ownership confirm these correlations (see Appendix Table AVI). This supports our conjecture that banks with better access to the interbank and capital markets can afford to maintain a larger open foreign currency position toward their customers.

A closer look at the wholesale assets and liabilities in our bank-level data reveals that banks with more foreign currency loans than deposits have a much lower foreign currency share of interbank assets, a lower share of foreign currency denominated securities and a higher share of foreign currency denominated interbank liabilities. ${ }^{23}$ In contrast, the open

21 Because our mortgage sample ends in 2008 we cannot perform this exercise for mortgage dollarization.

22 We report the results for the Russian bank-level data for 2010/2011 as this is the period for which we also have bank-level data from other Emerging European countries. We collected annual bank-level data for the entire period of our main analysis in Section 4.2 (2007-2014) and a crosssectional analysis for this longer period yields similar results to those we report for 2010/2011.

23 The pairwise correlation coefficients between, on the one hand, the open FX position and, on the other hand, the share of FX interbank assets, the share of FX denominated securities and the 

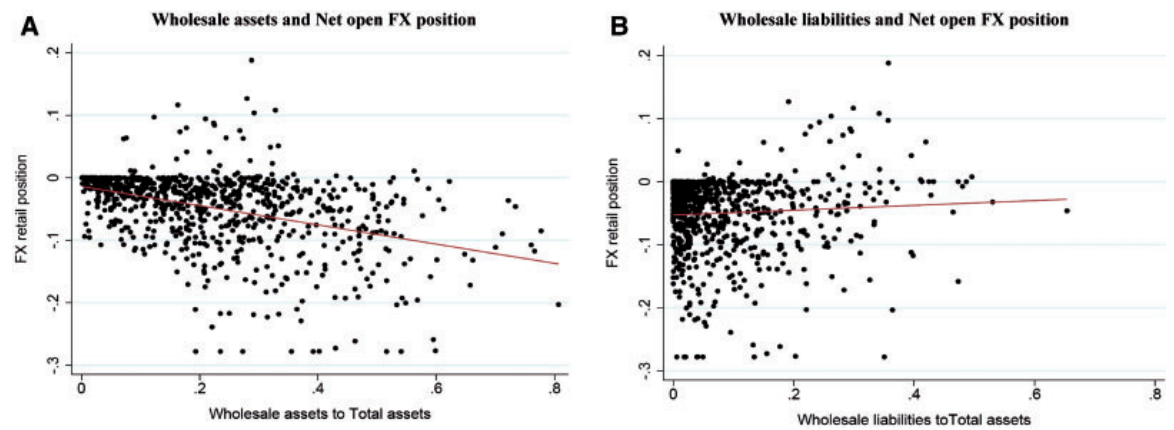

Figure 6. Wholesale assets, wholesale liabilities, and the open FX position toward customers-Banklevel data.

Notes: These graphs are based on bank-level financial statement data for 930 Russian banks in 2010/ 2011. They relate for each individual bank the net open fx position toward its customers ( $F X$ loans minus FX deposits, divided by total assets) to wholesale assets (as a share of total assets) in Panel A and to wholesale liabilities (as a share of total assets) in Panel B.

foreign currency position toward customers is unrelated to the foreign currency share of bond debt. Thus, Russian banks seem to match the currency structure of their customerrelated assets and liabilities by adjusting their position in the money market (as suggested by our model), but also by investing excess foreign currency deposits in foreign currency securities.

Contrary to Russia, banks in many other emerging markets are confronted with a long foreign currency position toward their customers: the demand for foreign currency loans exceeds the supply of foreign currency deposits. In this case, banks cannot accommodate their open position toward customers by investing in foreign currency assets. Instead, they access wholesale funding markets to source foreign currency funds. In the following we explore whether the relationship between a bank's open FX position toward customers and its access to wholesale and capital markets holds beyond the Russian context. To this end we use data from the 2011 Banking Environment and Performance Survey (BEPS II) of the European Bank for Reconstruction and Development. This survey covers 611 banks from thirty-two countries in Emerging Europe. For a subsample of 201 foreign-owned banks (from twenty-eight different countries) the survey reports information on the foreign currency composition of customer loans and deposits as well as the use of wholesale funding in 2010. In Appendix Table AVI, we relate the open FX position of these banks (as proxied by the FX share of loans minus the FX share of deposits) to their wholesale funding volume, controlling for bank size and location. Consistent with our earlier results, we find that also in this cross-country sample banks with more wholesale funding have larger net open FX positions toward their clients.

\section{Conclusions}

In this paper, we exploit regional variation in consumer price inflation in one of the world's largest currency blocks, the Russian Federation, to analyze the relationship between the

share of FX denominated interbank liabilities are $-0.25 ;-0.10$; and 0.20 , respectively (all significant at the $5 \%$ level). 
stability of the domestic currency and financial dollarization. We find robust evidence that regions with higher inflation exhibit stronger dollarization of household deposits and weaker dollarization of credit to firms in the non-tradable sectors as well as mortgage credit to households. The impact of inflation on credit dollarization is weaker in regions where the banking sector is less integrated. In these regions banks appear to adjust their lending structure to inflation-driven changes in the currency composition of deposit inflows.

Our findings shed new light on how inflation impacts on financial intermediation in (partly) dollarized economies. While inflation stimulates households to save in a foreign currency it simultaneously leads firms and households to borrow in the domestic currency. Price instability thus tends to create currency mismatches on banks' balance sheets. Banks that want to avoid such mismatches can take two courses of action. First, they can try to offload the FX deposits in the form of FX loans. In this way, they transfer the currency risk to (unhedged) households and firms who may actually prefer domestic currency loans. In this scenario, banks substitute (currency-induced) credit risk for direct balance sheet exposure to currency risk. Second, banks can reallocate the FX deposits elsewhere, either abroad or to branches in other regions where the demand for FX loans may be higher. Our results suggest that regionally integrated banks are better able to take this second course of action compared with local banks. Regional banking integration may therefore not only prevent banks from accumulating currency mismatches on their balance sheet, it also reduces the offloading of currency risks on households and unhedged firms and helps them to rebalance the currency composition of their financial portfolio.

While banking integration may increase financial stability by preventing the built up of currency mismatches on banks' or households' balance sheets, it may also expose regions to financial or business cycle shocks originating elsewhere, either in other regions (Imai and Takarabe, 2011; Loutskina and Strahan, 2015) or in other countries (Cetorelli and Goldberg, 2012; De Haas and Van Lelyveld, 2014). The impact of regional banking integration is therefore multifaceted and our analysis has only focused on one (important) mechanism through which banking integration may affect financial stability. A more complete analysis of the relationship between regional banking integration and financial instability, as well as real economic outcomes, appears to be a fruitful agenda for future research.

\section{Appendix. A Model of Regional Inflation and Financial Dollarization}

Consider an economy which is divided into many small regions. In each region $r$ there are $s_{r}$ savers each endowed with 1 unit of the domestic currency. For simplicity, we assume that in each region there are $b_{r}=s_{r}$ potential borrowers that would like to borrow the equivalent of 1 unit of the domestic currency. ${ }^{24}$

There is one price-taking bank in each region which offers term deposit accounts from $t=0$ to $t=1$ in domestic or foreign currency at interest rates $i_{d}^{l}$ and $i_{d}^{f}$, respectively. The bank also offers one-period credit in domestic or foreign currency at interest rates $i_{c}^{l}$ and $i_{c}^{f}$, respectively. The transaction costs to the bank of acquiring one unit of deposits are $k_{d}$ and the transaction costs for dispersing one unit of credit are $k_{c}$. We account for potential

24 For simplicity, we assume that the aggregate supply and demand of funds in each region are identical. This allows us to focus on the currency composition of deposit supply and loan demand, which we study in our empirical analysis. 
market power of the bank in each region by assuming that it can charge a mark-up $q_{d}$ and $q_{c}$ in the deposit and credit market, respectively. Note that as we assume that the markets for local and foreign currency deposits are fully integrated - that is, the bank faces the same potential clients for both currencies-it is consistent to assume that transaction costs and mark-ups are independent of the currency of funds. The same applies to the loan market. We abstract from credit risk and assume that due to prudential regulation or internal risk management, banks must match the currency structure of their assets and liabilities.

\section{Exchange Rate Expectations}

The exchange rate between the domestic and foreign currency is normalized to $e_{0}=1$ at $t=0$. We assume that banks in all regions have a common exchange rate expectation for $t=1$ which is embedded in the forward rate $e_{m}$. We also assume that exchange rate expectations are heterogeneous across savers and borrowers. Borrowers and savers base their exchange rate expectations on economy-wide public signals as well as heterogeneous, private, and local signals. We assume that savers and borrowers in each region form exchange rate expectations based on the observed market forward rate $e_{m}$ and local consumer price inflation $p_{r}$. Based on this observation each agent $j$ forms expectations:

$$
e_{j}=e_{j}\left(e_{m}, p_{r}\right)
$$

$$
\text { where } \frac{\partial e_{i}}{\partial e_{m}}, \frac{\partial e_{i}}{\partial p_{r}}>0 \text {. }
$$

Our modeling of exchange rate expectations suggests that higher observed regional inflation will translate into stronger depreciation expectations for households and firms in that region. Our general formulation of expectation formation allows for differences in exchange rate formation across savers or borrowers within a region. For example, more sophisticated and better informed agents may place more weight on the market forward rate than on local inflation. Our assumption about heterogeneous exchange rate expectations is consistent with survey evidence for emerging markets (Carlson and Valev, 2001).

In the following we use the notation $\Delta e_{m}=e_{m}-e_{0}=e_{m}-1$ and $\Delta e_{j}=e_{j}-e_{0}=e_{j}-1$ to denote the expected depreciation of the local currency as perceived by the market and by agent $j$, respectively.

\section{The Currency Structure of Deposits and Loans}

We assume that the total supply of deposits by savers is given: each saver deposits his endowment with the local bank, so that the total supply of deposits in region $r$ is $s_{r}$. Savers decide only whether to hold deposits in domestic or foreign currency. We assume that savers are risk-neutral. ${ }^{25}$ We also assume that households make payments predominantly in domestic currency, so that they are interested in the expected value of their savings in domestic currency at $t=1$. A saver with the individual exchange rate

25 We abstract from risk aversion here to focus on the role of regional inflation and banking integration. With risk-average savers and borrowers the currency choice of deposits and loans would not only be determined by interest rate differentials and expected depreciation (inflation) but also by the expected volatility of inflation and the real exchange rate. See Ize and Levy-Yeyati (2003) for a portfolio model with risk-averse investors. 
expectation $e_{j}$ will thus deposit his endowment in foreign currency if $1+i_{d}^{l} \leq 1+i_{d}^{f}+\Delta$ $e_{j}$ and thus if

$$
i_{d}^{l}-i_{d}^{f} \leq \Delta e_{j}
$$

We assume that each borrower is characterized by a non-stochastic investment return $\pi$ in the domestic currency. We assume that for feasible interest rates and exchange rate expectations the expected return on a domestic currency loan and foreign currency loan are both positive.

$$
\pi-\left(1+i_{c}^{l}\right) \geq 0 ; \pi-\left(1+i_{c}^{f}+\Delta e_{j}\right) \geq 0 .
$$

Given this assumption, borrowers decide only whether to take a loan in domestic or foreign currency. They will prefer to borrow in foreign currency if:

$$
i_{c}^{l}-i_{c}^{f} \geq \Delta e_{j}
$$

We define $\gamma_{r}\left(p_{r}, i_{d}^{l}-i_{d}^{f}\right)$ as the share of savers for which Condition (A.2) holds. Likewise we define $\delta_{r}\left(p_{r}, i_{c}^{l}-i_{c}^{f}\right)$ as the share of borrowers for which Condition (A.3) holds. As we have assumed in Equation (A.1) that expected depreciation by savers and borrowers is increasing in locally observed inflation we can assert from Conditions (A.2) and (A.3) that the share of foreign currency deposits (loans) in a region increases (decreases) ceteris paribus with regional inflation. That is, $\frac{\partial \gamma_{r}}{\partial p_{r}}>0, \frac{\partial \delta_{r}}{\partial p_{r}}<0$.

\section{Banking Integration}

We assume that regional banking markets are integrated via a money market in which domestic and foreign currency funds are traded competitively. ${ }^{26}$ The interest rates on domestic and foreign currency money market funds are $i_{m}^{l}$ and $i_{m}^{f}$, respectively. The interest rate differential on money-market funds is governed by the covered interest rate parity:

$$
i_{m}^{l}=i_{m}^{f}+\Delta e_{m} .
$$

The bank will offer the following interest rates:

$$
\begin{aligned}
& i_{d}^{l}=i_{m}^{l}-k_{d}-q_{d} . \\
& i_{d}^{f}=i_{m}^{f}-k_{d}-q_{d} . \\
& i_{c}^{l}=i_{m}^{l}+k_{c}+q_{c} . \\
& i_{c}^{f}=i_{m}^{f}+k_{c}+q_{c} .
\end{aligned}
$$

26 We assume that no region is large enough so that its bank has market power in the money market. An alternative and equivalent way of modeling bank integration would be to assume that banks in each region are branches or subsidiaries of a large bank (holding) company which operates an internal capital market with fixed transfer prices for domestic-currency and foreign-currency funds. 
Under our assumption of identical transaction costs and market power across currencies, the intermediation spread in domestic or foreign currency is identical and determined by the costs of intermediation and market power of the bank in the deposit and loan market:

$$
i_{c}^{l}-i_{d}^{l}=i_{c}^{f}-i_{d}^{f}=k_{c}+k_{d}+q_{d}+q_{c} .
$$

Furthermore, our assumption of integrated banking markets and interest rate parity implies that the currency spread, that is, the interest rate differentials between domestic currency and foreign currency funds, is identical for loans and deposits and is given by the expected depreciation implied in the forward rate $e_{m}$ :

$$
\begin{aligned}
& i_{d}^{l}-i_{d}^{f}=i_{m}^{l}-i_{m}^{f}=\Delta e_{m} . \\
& i_{c}^{l}-i_{c}^{f}=i_{m}^{l}-i_{m}^{f}=\Delta e_{m} .
\end{aligned}
$$

Given these interest rates, savers will choose to deposit in foreign currency if:

$$
\Delta e_{m} \leq \Delta e_{j}\left(p_{r}\right) .
$$

In contrast, borrowers will prefer a loan in foreign currency if:

$$
\Delta e_{m} \geq \Delta e_{j}\left(p_{r}\right) .
$$

All savers for which Condition (A.2a) holds deposit their endowment in foreign currency. The bank has $\gamma_{r} \cdot s_{r}$ deposits in foreign currency and $\left[1-\gamma_{r}\right] \cdot s_{r}$ in domestic currency. All borrowers for which Condition (A.3a) holds take a loan in foreign currency. The bank has $\delta_{r} \cdot s_{r}$ loans in foreign currency and $\left[1-\delta_{r}\right] \cdot s_{r}$ loans in domestic currency. The bank matches the currency composition of its liabilities and assets by borrowing or lending in the money market. In the foreign (domestic) currency money market it borrows (lends) the following amount: $\left[\delta_{r}-\gamma_{r}\right] \cdot s_{r}$.

A ceteris paribus increase in regional inflation $p_{r}$ will increase the share of foreign deposits $\gamma_{r}$ and reduce the demand for foreign currency loans $\delta_{r}$. There will be an increase in the foreign currency share of deposit dollarization and a reduction of credit dollarization. The bank will adapt to the change in regional deposit supply and credit demand by altering its borrowing or lending in the interbank market.

\section{Autarky}

Now assume that regional banking markets are not integrated. This implies that the regional supply of domestic currency and foreign currency deposits must be congruent with the demand for domestic currency and foreign currency loans. This is the case if:

$$
\gamma_{r}\left(p_{r}, i_{d}^{l}-i_{d}^{f}\right)=\delta_{r}\left(p_{r}, i_{c}^{l}-i_{c}^{f}\right)
$$

We assume that banks do not have access to the money market. This implies that the intermediation spreads in domestic or foreign currency are given by the costs of intermediation and market power of the bank in the deposit and loan market:

$$
i_{c}^{l}-i_{d}^{l}=i_{c}^{f}-i_{d}^{f}=k_{c}+k_{d}+q_{d}+q_{c}
$$

The currency spread on deposits and loans $i_{c}^{f}-i_{c}^{l}=i_{d}^{f}-i_{d}^{l}$ is still independent of the 
transaction costs and market power of banks. Importantly though, the currency spread is no longer governed by the forward rate in the money market.

An increase in $p_{r}$ will ceteris paribus increase the supply of foreign currency deposits $\gamma_{r}$ $\left(p_{r}\right)$ and decrease demand for foreign currency loans $\delta_{r}\left(p_{r}\right)$. The bank must alter the currency spread $i_{c}^{f}-i_{c}^{l}=i_{d}^{f}-i_{d}^{l}$ so that the demand and supply of domestic currency (foreign currency) funds equalize. The reaction of foreign currency deposits and loans to a change in regional inflation (and thus exchange rate expectations) is less divergent under autarky than under integrated banking markets. Whether a bank accommodates the (inflation-induced) change in the currency composition of loan demand and deposit supply more through the deposit market or through the loan market will depend on the relative sensitivity of loan currency composition and deposit currency composition to the currency spread. 
Table Al. Variable definitions and data sources

CBR and Rosstat are the Central Bank and the Federal State Statistics Service of the Russian Federation, respectively. All dependent variables are on a constant currency basis by adjusting the reported FX amounts using the exchange-rate change over the reported period. BEPS II: EBRD BEPS II.

\begin{tabular}{|c|c|c|c|}
\hline & Definition & Source & Unit \\
\hline \multicolumn{4}{|l|}{ Dependent variables } \\
\hline $\begin{array}{l}\Delta \text { Deposit } \\
\text { dollarization }\end{array}$ & $\begin{array}{l}\text { Quarterly change in the share of FX household deposits } \\
\text { with banks in a region/total household deposits with } \\
\text { banks in a region }\end{array}$ & CBR & $\%$ point \\
\hline $\begin{array}{l}\Delta \text { Firm loan } \\
\text { dollarization }\end{array}$ & $\begin{array}{l}\text { Quarterly change in the share of FX credit to firms in a } \\
\text { region/total credit to firms in a region }\end{array}$ & CBR & $\%$ point \\
\hline $\begin{array}{l}\Delta \text { Firm loan } \\
\text { dollarization: } \\
\text { Non-tradables }\end{array}$ & $\begin{array}{l}\text { Quarterly change in the share of FX credit to firms in } \\
\text { non-tradable sectors in a region/total credit to firms } \\
\text { in non-tradable sectors in a region }\end{array}$ & CBR & $\%$ point \\
\hline $\begin{array}{l}\Delta \text { Firm loan } \\
\text { dollarization: } \\
\text { Tradables }\end{array}$ & $\begin{array}{l}\text { Quarterly change in the share of FX credit to firms in } \\
\text { tradable sectors in a region/total credit to firms in } \\
\text { tradable sectors in a region }\end{array}$ & CBR & $\%$ point \\
\hline $\begin{array}{l}\Delta \text { Mortgage } \\
\text { dollarization }\end{array}$ & $\begin{array}{l}\text { New FX mortgage lending by banks in a region/total } \\
\text { new mortgage lending by banks in a region }\end{array}$ & CBR & $\%$ \\
\hline \multicolumn{4}{|c|}{ Independent variables } \\
\hline$\Delta$ Inflation & $\begin{array}{l}\text { One quarter lagged year-on-year inflation change based } \\
\text { on a fixed basket of consumer goods (same basket } \\
\text { applies to all Russian regions) }\end{array}$ & Rosstat & $\%$ \\
\hline $\begin{array}{l}\text { Inflation } \\
\text { volatility }\end{array}$ & $\begin{array}{l}\text { Moving standard deviation of regional monthly infla- } \\
\text { tion over the past } 12 \text { months (one quarter lagged) }\end{array}$ & Rosstat & $\%$ \\
\hline $\begin{array}{l}\text { Growth trade } \\
\text { openness }\end{array}$ & $\begin{array}{l}\text { Quarterly growth of regional trade with foreign coun- } \\
\text { tries defined as the average of the sum of regional } \\
\text { world exports plus regional world imports }\end{array}$ & Rosstat & $\%$ \\
\hline $\begin{array}{l}\text { Growth value } \\
\text { tradables }\end{array}$ & $\begin{array}{l}\text { Quarterly growth of regional value added of the manu- } \\
\text { facturing and commodity-extraction industries }\end{array}$ & Rosstat & $\%$ \\
\hline $\begin{array}{l}\text { Growth value } \\
\text { non-tradables }\end{array}$ & $\begin{array}{l}\text { Quarterly growth of regional value added of the con- } \\
\text { struction, electricity generation, services, retail, and } \\
\text { wholesale trade industries }\end{array}$ & Rosstat & $\%$ \\
\hline $\begin{array}{l}\text { Growth govern- } \\
\text { ment } \\
\text { expenditures }\end{array}$ & Quarterly growth of regional government spending & Rosstat & $\%$ \\
\hline $\begin{array}{l}\text { Proportion local } \\
\text { banks }\end{array}$ & $\begin{array}{l}\text { Number of banks registered in the region as a propor- } \\
\text { tion of the total number of banks in the region (i.e., } \\
\text { both local banks and branches of inter-regional } \\
\text { banks) in 2004-05 }\end{array}$ & CBR & Share \\
\hline $\begin{array}{l}\text { Proportion local } \\
\text { bank branches }\end{array}$ & $\begin{array}{l}\text { Number of branches and all offices of banks registered } \\
\text { in the region as a proportion of the total number of } \\
\text { branches and all offices of banks in the region (i.e., } \\
\text { both local bank branches and offices and branches } \\
\text { and offices of inter-regional banks) in } 2013\end{array}$ & BEPS II & Share \\
\hline
\end{tabular}


Table Al. Continued

\begin{tabular}{|c|c|c|c|}
\hline & Definition & Source & Unit \\
\hline $\begin{array}{l}\text { Proportion local } \\
\text { bank liabilities }\end{array}$ & $\begin{array}{l}\text { Liabilities of banks registered in a region as a propor- } \\
\text { tion of total liabilities of all banks operating in a } \\
\text { region in 2004-05 (liabilities include accounts of } \\
\text { firms and government bodies, firm deposits, house- } \\
\text { hold deposits, and loans from other banks) }\end{array}$ & CBR & Share \\
\hline Bank entry & $\begin{array}{l}\text { Dummy that is ' } 1 \text { ' if at least one new bank entered a } \\
\text { region in a given quarter }\end{array}$ & CBR & $0 / 1$ \\
\hline Bank exit & $\begin{array}{l}\text { Dummy that is ' } 1 \text { ' if at least one bank exited a region in } \\
\text { a given quarter }\end{array}$ & CBR & $0 / 1$ \\
\hline Wildfires & $\begin{array}{l}\text { Intensity of wild fires as measured by the ratio between } \\
\text { the area affected by wild fires (in hundreds of } \mathrm{m}^{2} \text { ) to } \\
\text { the number of reported fires. }\end{array}$ & Rosstat & Share \\
\hline
\end{tabular}

Table All. Summary statistics

\begin{tabular}{lrrrrrr}
\hline & Observation & Mean & Median & $\begin{array}{r}\text { Standard } \\
\text { deviation }\end{array}$ & Min & Max \\
& & & & & & \\
& & & & & & \\
Dependent variables & & & & & \\
$\Delta$ Deposit dollarization & 2,272 & -0.41 & -0.34 & 0.78 & -3.76 & 2.02 \\
$\Delta$ Firm loan dollarization & 2,272 & -0.23 & -0.16 & 2.75 & -9.52 & 11.13 \\
$\Delta$ Firm loan dollarization: non-tradables & 2,272 & -0.26 & -0.05 & 3.38 & -10.49 & 9.75 \\
$\Delta$ Firm loan dollarization: tradables & 2,272 & -0.23 & -0.16 & 3.13 & -11.12 & 11.55 \\
$\Delta$ Mortgage dollarization & 636 & 10.23 & 7.29 & 9.38 & 0.00 & 54.72 \\
Independent variables & & & & & & \\
$\Delta$ Inflation & 2,272 & -0.28 & -0.19 & 5.49 & -25.27 & 21.27 \\
Inflation volatility & 2,627 & 1.20 & 1.13 & 0.50 & 0.25 & 2.27 \\
Growth trade openness & 2,258 & 4.50 & 5.76 & 35.61 & -118.34 & 128.48 \\
Growth value tradables & 2,556 & 4.79 & 6.69 & 20.19 & -58.90 & 63.66 \\
Growth value non-tradables & 2,556 & 8.12 & 7.53 & 32.61 & -47.12 & 31.84 \\
Growth government expenditures & 2,627 & 16.90 & 5.76 & 13.89 & -14.62 & 61.65 \\
Proportion local banks & 71 & 0.29 & 0.27 & 0.15 & 0.00 & 0.73 \\
Proportion local bank branches & 71 & 0.09 & 0.07 & 0.08 & 0.00 & 0.50 \\
Proportion local bank liabilities & 71 & 0.23 & 0.17 & 0.19 & 0.00 & 0.94 \\
Bank entry & 2,272 & 0.05 & 0.00 & 0.22 & 0.00 & 1.00 \\
Bank exit & 2,272 & 0.27 & 0.00 & 0.44 & 0.00 & 1.00 \\
Wildfires & 70 & 0.02 & 0.01 & 0.07 & 0.00 & 0.45 \\
& & & & & &
\end{tabular}




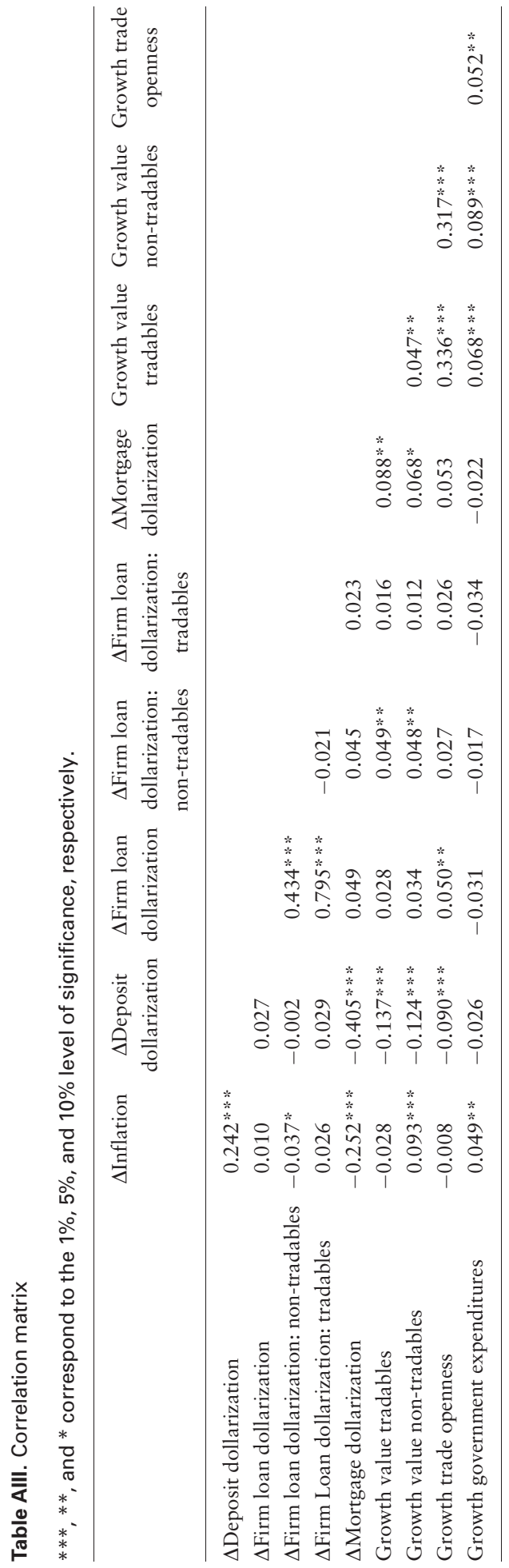


Table AIV. Robustness: including inflation volatility

This table shows OLS regressions to estimate the impact of the change in regional consumer price inflation on the change in dollarization across Russia's regions while controlling for regional inflation volatility. Sample period: Q2 2005-Q2 2008 and Q4 2009-Q2 2014. Robust standard errors are clustered by region and $t$-statistics appear in parentheses. ***, **, and * correspond to the $1 \%, 5 \%$, and $10 \%$ level of significance, respectively. Table Al in the Appendix contains all variable definitions.

\begin{tabular}{|c|c|c|c|c|c|}
\hline & \multirow{2}{*}{$\begin{array}{c}\Delta \text { Deposit } \\
\text { dollarization } \\
{[1]}\end{array}$} & \multicolumn{4}{|c|}{$\Delta$ Loan dollarization } \\
\hline & & $\begin{array}{c}\text { Firms } \\
{[2]}\end{array}$ & $\begin{array}{c}\text { Firms: } \\
\text { non-tradables } \\
{[3]}\end{array}$ & $\begin{array}{c}\text { Firms: } \\
\text { tradables } \\
{[4]}\end{array}$ & $\begin{array}{c}\text { Mortgage } \\
{[5]}\end{array}$ \\
\hline$\Delta$ Inflation & $\begin{array}{l}0.010 * * * \\
(3.150)\end{array}$ & $\begin{array}{c}-0.028^{*} \\
(1.716)\end{array}$ & $\begin{array}{c}-0.057 * \\
(2.234)\end{array}$ & $\begin{array}{r}-0.006 \\
(0.321)\end{array}$ & $\begin{array}{c}-0.191 * * \\
(2.441)\end{array}$ \\
\hline Inflation volatility & $\begin{array}{c}0.038 \\
(1.597)\end{array}$ & $\begin{array}{c}0.028 \\
(0.170)\end{array}$ & $\begin{array}{c}0.083 \\
(0.371)\end{array}$ & $\begin{array}{c}0.113 \\
(0.609)\end{array}$ & $\begin{array}{c}0.742 \\
(0.831)\end{array}$ \\
\hline Growth trade openness & $\begin{array}{l}0.001 * * \\
(2.041)\end{array}$ & $\begin{array}{l}0.003 * * \\
(2.092)\end{array}$ & $\begin{array}{r}-0.000 \\
(0.134)\end{array}$ & $\begin{array}{c}0.002 \\
(0.912)\end{array}$ & $\begin{array}{r}-0.001 \\
(0.153)\end{array}$ \\
\hline Growth value tradables & $\begin{array}{r}-0.000 \\
(0.527)\end{array}$ & $\begin{array}{c}0.001 \\
(0.241)\end{array}$ & $\begin{array}{c}0.007 \\
(1.294)\end{array}$ & $\begin{array}{r}-0.001 \\
(0.021)\end{array}$ & $\begin{array}{r}-0.011 \\
(0.891)\end{array}$ \\
\hline Growth value non-tradables & $\begin{array}{r}-0.000 \\
(0.165)\end{array}$ & $\begin{array}{c}0.002 \\
(0.253)\end{array}$ & $\begin{array}{c}0.005 \\
(0.573)\end{array}$ & $\begin{array}{r}-0.005 \\
(0.548)\end{array}$ & $\begin{array}{c}-0.037^{*} \\
(1.647)\end{array}$ \\
\hline Growth government expenditures & $\begin{array}{c}-0.002 * \\
(1.871)\end{array}$ & $\begin{array}{c}0.002 \\
(0.381)\end{array}$ & $\begin{array}{c}0.002 \\
(0.396)\end{array}$ & $\begin{array}{r}-0.001 \\
(0.262)\end{array}$ & $\begin{array}{c}0.036 \\
(1.432)\end{array}$ \\
\hline Region FE & Yes & Yes & Yes & Yes & Yes \\
\hline Time FE & Yes & Yes & Yes & Yes & Yes \\
\hline Bank entry-exit dummies & Yes & Yes & Yes & Yes & Yes \\
\hline Observations & 2,258 & 2,258 & 2,258 & 2,258 & 636 \\
\hline Regions & 71 & 71 & 71 & 71 & 71 \\
\hline$R$-squared & 0.69 & 0.16 & 0.13 & 0.14 & 0.13 \\
\hline
\end{tabular}


Table AV. Regional inflation and financial dollarization across Russia: GMM

This table shows Arellano-Bond (1991) GMM regressions to estimate the impact of regional consumer price inflation on dollarization across Russia's regions. Sample period: Q2 2005Q2 2008 and Q4 2009-Q2 2014. Robust standard errors are clustered by region and $t$-statistics appear in parentheses. ${ }^{* *},{ }^{*}$, and ${ }^{*}$ correspond to the $1 \%, 5 \%$, and $10 \%$ level of significance, respectively. Table $\mathrm{A} 1$ in the Appendix contains all variable definitions.

\begin{tabular}{|c|c|c|c|c|c|}
\hline & \multirow{2}{*}{$\begin{array}{c}\text { Deposit } \\
\text { dollarization } \\
\\
{[1]}\end{array}$} & \multicolumn{4}{|c|}{ Loan dollarization } \\
\hline & & $\begin{array}{l}\text { Firms: } \\
\text { total } \\
{[2]}\end{array}$ & $\begin{array}{c}\text { Firms: } \\
\text { non-tradables } \\
{[3]}\end{array}$ & $\begin{array}{c}\text { Firms: } \\
\text { tradables } \\
{[4]}\end{array}$ & $\begin{array}{c}\text { Mortgages } \\
{[5]}\end{array}$ \\
\hline Inflation & $\begin{array}{c}0.029^{* * * *} \\
(7.288)\end{array}$ & $\begin{array}{c}-0.037^{*} \\
(1.880)\end{array}$ & $\begin{array}{c}-0.079 * * \\
(2.171)\end{array}$ & $\begin{array}{l}-0.024 \\
(0.979)\end{array}$ & $\begin{array}{c}-0.469^{* * *} \\
(3.705)\end{array}$ \\
\hline Region FE & Yes & Yes & Yes & Yes & Yes \\
\hline Time FE & Yes & Yes & Yes & Yes & Yes \\
\hline Bank entry-exit dummies & Yes & Yes & Yes & Yes & Yes \\
\hline Observations & 2,055 & 1,980 & 1,909 & 1,984 & 420 \\
\hline Regions & 71 & 71 & 71 & 71 & 70 \\
\hline $\operatorname{AR}(1)$ & 0.000 & 0.000 & 0.000 & 0.000 & 0.001 \\
\hline $\mathrm{AR}(2)$ & 0.120 & 0.584 & 0.565 & 0.250 & 0.253 \\
\hline
\end{tabular}


Table AVI. Wholesale assets, wholesale liabilities, and open FX positions

This table shows OLS regressions to estimate the relation between banks' wholesale assets, wholesale liabilities, and their net open FX position toward customers. Column [1] is based on 930 Russian banks using balance sheet data for 2010 (source: Central Bank of Russia). The dependent variable is FX open position: FX loans minus FX deposits, divided by total assets. Wholesale assets are defined as interbank assets plus investments in securities, divided by total assets. Wholesale liabilities are defined as interbank liabilities plus bond debt, divided by total assets. State bank and Foreign bank are dummies that are "1" for state-owned and foreignowned banks, respectively. Column [2] is based on 2011 data from the BEPS II survey for 201 foreign banks from twenty-eight emerging European countries. The dependent variable is Net FX share: the share of FX loans minus the share of FX deposits. Wholesale funding is the log of interbank funding (in USD). EU country is a dummy for banks located in an EU member state. Robust standard errors in parentheses. ${ }^{* *},{ }^{* *}$, and ${ }^{*}$ correspond to the $1 \%, 5 \%$, and $10 \%$ level of significance, respectively.

\begin{tabular}{|c|c|c|}
\hline $\begin{array}{l}\text { Sample } \\
\text { Dependent variable }\end{array}$ & $\begin{array}{c}\text { Russian banks } \\
\text { FX open position } \\
{[1]}\end{array}$ & $\begin{array}{c}\text { Emerging European banks } \\
\text { Net FX share } \\
{[2]}\end{array}$ \\
\hline Wholesale assets & $\begin{array}{l}-0.127 * * * \\
(0.013)\end{array}$ & \\
\hline Wholesale liabilities & $\begin{array}{l}0.219 * * * \\
(0.025)\end{array}$ & \\
\hline Wholesale funding & & $\begin{array}{c}0.024 * \\
(0.013)\end{array}$ \\
\hline Total assets $(\log )$ & $\begin{array}{l}-0.006 * * * \\
(0.001)\end{array}$ & $\begin{array}{c}0.001 \\
(0.019)\end{array}$ \\
\hline State bank & $\begin{array}{c}0.015 \\
(0.019)\end{array}$ & \\
\hline Foreign bank & $\begin{array}{l}0.071 * * * \\
(0.014)\end{array}$ & \\
\hline EU country & & $\begin{array}{c}0.055 \\
(0.045)\end{array}$ \\
\hline$R$-squared & 0.32 & 0.06 \\
\hline Observations & 930 & 201 \\
\hline
\end{tabular}

\section{References}

Bacchetta, P. and van Wincoop, E. (2013) On the unstable relationship between exchange rates and macroeconomic fundamentals, Journal of International Economics 91, 18-26.

Basso, H. S., Calvo-Gonzalez, O., and Jurgilas, M. (2010) Financial dollarization and the role of banks and interest rates, Journal of Banking and Finance 35, 794-806.

Beck, G. W., Hubrich, K., and Marcellino, M. (2009) Regional inflation dynamics within and across euro area countries and a comparison with the US, Economic Policy 24, 141-184.

Beckmann, E. and Stix, H. (2015) Foreign currency borrowing and knowledge of exchange rate risk, Journal of Economic Behavior \& Organization 112, 1-16.

Boyd, J. H., Levine, R., and Smith, B. D. (2001) The impact of inflation on financial sector performance, Journal of Monetary Economics 47, 221-248.

Brown, M. and De Haas, R. (2012) Foreign banks and foreign currency lending in emerging Europe, Economic Policy 27, 57-98. 
Brown, M., Kirschenmann, K., and Ongena, S. (2014) Bank funding, securitization, and loan terms: evidence from foreign currency lending, Journal of Money, Credit, and Banking 46, 1501-1534.

Brown, M. and Stix, H. (2015) The euroization of bank deposits in Eastern Europe, Economic Policy 30, 1-45.

Brückner, M. and Ciccone, A. (2011) Rain and the democratic window of opportunity, Econometrica 79, 923-947.

Burke, P. J. and Leigh, A. (2010) Do output contractions trigger democratic change?, American Economic Journal: Macroeconomics 2, 124-157.

Calvo, G. A. (2001) Capital markets and the exchange rate: with special reference to the dollarization debate in Latin America, Journal of Money, Credit, and Banking 33, 312-334.

Carlson, J. and Valev, N. (2001) Credibility of a new monetary regime: the currency board in Bulgaria, Journal of Monetary Economics 47, 581-594.

Cetorelli, N. and Goldberg, L. S. (2012) Liquidity management of U.S. global banks: internal capital markets in the great recession, Journal of International Economics 88, 299-311.

Craig, B. and Waller, C. J. (2004) Dollarization and currency exchange, Journal of Monetary Economics 51, 671-689.

Cremers, M., Huang, R., and Sautner, Z. (2011) Internal capital markets and corporate politics in a banking group, Review of Financial Studies 24, 358-401.

De Gregorio, J., Giovannini, A., and Wolf, H. C. (1994) International evidence on tradables and nontradables inflation, European Economic Review 38, 1245-1249.

De Haas, R. and Van Lelyveld, I. (2014) Multinational banks and the global financial crisis. Weathering the perfect storm?, Journal of Money, Credit, and Banking 46, 333-364.

De Nicoló, G., Honohan, P., and Ize, A. (2005) Deposit dollarization: causes and consequences, Journal of Banking \& Finance 29, 1697-1727.

Engineer, M. (2000) Currency transaction costs and competing fiat currencies, Journal of International Economics 52, 116-136.

Fratzscher, M., Rime, D., Sarno, L., and Zinna, G. (2015) The scapegoat theory of exchange rates: the first tests, Journal of Monetary Economics 70, 1-21.

Garcia-Escribano, M. and Sosa, S. (2011) What is driving financial de-dollarization in Latin America? IMF Working Paper 11/10, International Monetary Fund, Washington, DC.

Gluschenko, K. (2001) Inter-regional variability of inflation rates. Economics Education and Research Consortium Working Paper Series, Institute of Economics and Industrial Engineering, Novosibirsk.

Gluschenko, K. (2013) Dynamics of regional price distribution over 2001-2010. Unpublished working paper (in Russian).

Imai, M. and Takarabe, S. (2011) Bank integration and transmission of financial shocks: evidence from Japan, American Economic Journal: Macroeconomics 3, 155-183.

Ize, A. and Levy-Yeyati, E. (2003) Financial dollarization, Journal of International Economics 59, 323-347.

Jensen, J. B. and Kletzer, L. G. (2005) Tradable services: understanding the scope and impact of services outsourcing. Unpublished working paper, Working Paper Series WP05-9, Peterson Institute for International Economics.

Lazarev, E., Sobolev, A., Soboleva, I. V., and Sokolov, B. (2014) Trial by fire: a natural disaster's impact on support for the authorities in rural Russia, World Politics 66, 641-668.

Lin, S. and Ye, H. (2013) Does inflation targeting help reduce financial dollarization?, Journal of Money, Credit and Banking 45, 1253-1274.

Loutskina, E. and Strahan, P. E. (2015) Financial integration, housing, and economic volatility, Journal of Financial Economics 115, 25-41.

Luca, A. and Petrova, I. (2008) What drives credit dollarization in transition economies?, Journal of Banking and Finance 32, 858-869. 
Lucas, R. E. (1972) Expectations and the neutrality of money, Journal of Economic Theory 4, 103-124.

Miguel, E., Satyanath, S., and Sergenti, E. (2004) Economic shocks and civil conflicts: an instrumental variables approach, Journal of Political Economy 112, 725-753.

Morgan, D. P., Rime, B., and Strahan, P. E. (2004) Bank integration and state business cycles, Quarterly Journal of Economics 119, 1555-1585.

Morris, S. and Shin, H. S. (2002) Social value of public information, American Economic Review 92, 1521-1534.

Myatt, D. P. and Wallace, C. (2014) Central bank communication design in a Lucas-Phelps economy, Journal of Monetary Economics 63, 64-79.

Nagayasu, J. (2011) Heterogeneity and convergence of regional inflation (prices), Journal of Macroeconomics 33, 711-723.

Ongena, S., Schindele, I., and Vonnák, D. (2015) In lands of foreign currency credit, bank lending channels run through? CFS Working Paper No. 474, Center for Financial Studies, University of Frankfurt.

Phelps, E. S. (1970). Introduction: the new microeconomics in employment and inflation theory, in: G. Archibald, A. A. Alchian, and E. S. Phelps (eds.), Microeconomic Foundations of Employment and Inflation Theory, Norton, New York, pp. 1-23.

Schultz, A. and Libman, A. (2015) Is there a local knowledge advantage in federations? Evidence from a natural experiment, Public Choice 162, 25-42.

Uribe, M. (1997) Hysteresis in a simple model of currency substitution, Journal of Monetary Economics 40, 185-202.

Valev, N. T. (2010) The hysteresis of currency substitution: currency risk vs. network externalities, Journal of International Money and Finance 29, 224-235.

Vaone, A. and Ascari, G. (2012) Regional inflation persistence: evidence from Italy, Regional Studies 46, 509-523.

World Bank. (2013) Europe and Central Asia Housing Finance Crisis Prevention and Resolution. A Review of Policy Options, The World Bank, March. 